\title{
«ENTRE ALEGRE ESPERANZA Y TRISTE OLVIDO» \\ (VERSOS INÉDITOS DE JUAN BAUTISTA DE VIVAR \\ EN LA BIBLIOTECA RICCARDIANA DE FLORENCIA)
}

ABRAHAM MADROÑAL

CSIC

\section{Juan Bautista de Vivar, poeta Relacionado con CERVANTES}

En un lugar de la segunda parte del Quijote (II, 18), después de un diálogo con don Lorenzo, hijo de don Diego de Miranda, que estaba enfrascado en una justa literaria en que se pedía glosar unos versos, se pronuncia Cervantes sobre la arrogancia de los poetas, la injusticia de los premios y la manía de glosar, y pone en boca de su protagonista lo siguiente:

«Un amigo y discreto - respondió don Quijote- era de parecer que no se había de cansar nadie en glosar versos, y la razón, decía él, era que jamás la glosa podía llegar al texto, y que muchas o las más veces iba la glosa fuera de la intención y propósito de lo que pedía lo que se glosaba, y más, que las leyes de la glosa eran demasiadamente estrechas, que no sufrían interrogantes, ni dijo, ni diré, ni hacer nombres de verbos, ni mudar el sentido, con otras ataduras y estrechezas con que van atados los que glosan, como vuestra merced debe de saber».

Parece, pues, que Cervantes era de la opinión de que la moda de glosar versos o de pedir que se glosasen, como si de un pie forzado se tratara, no dejaba de ser un disparate. Para ejemplificarlo, inmediatamente se pone como ejemplo la presente glosa a estos versos:

"iSi mi fue tornase a es,

sin esperar más será,

o viniese el tiempo ya

de lo que será después...!

AC, XXXVI (2004), 101-164 
Glosa

Al fin, como todo pasa, se pasó el bien que me dio fortuna, un tiempo no escasa, y nunca me le volvió, ni abundante ni por tasa. Siglos ha ya que me vees, fortuna, puesto a tus pies: vuélveme a ser venturoso, que será mi ser dichoso si mi fue tornase a es.

No quiero otro gusto o gloria, otra palma o vencimiento, otro triunfo, otra vitoria, sino volver al contento que es pesar en mi memoria. Si tú me vuelves allá, Fortuna, templado está Todo el rigor de mi fuego, Y más si este bien es luego, sin esperar más será.
Cosas imposibles pido, pues volver el tiempo a ser después que una vez ha sido, no hay en la tierra poder que a tanto se haya estendido. Corre el tiempo, vuela y va ligero, y no volverá, y erraría el que pidiese, o que el tiempo ya se fuese o viniese el tiempo ya.

Vivir en perpleja vida, ya esperando, ya temiendo, es muerte muy conocida, y es mucho mejor muriendo buscar al dolor salida. A mí me fuera interés acabar, mas no lo es, pues, con discurso mejor, me da la vida el temor de lo que será después.

En acabando de decir su glosa don Lorenzo, se levantó en pie don Quijote, y en voz levantada, que parecía grito, asiendo con su mano la derecha de don Lorenzo, dijo:

- iViven los cielos donde más altos están, mancebo generoso, que sois el mejor poeta del orbe, y que merecéis estar laureado, no por Chipre ni por Gaeta, como dijo un poeta que Dios perdone, sino por las academias de Atenas, si hoy vivieran, y por las que hoy viven de París, Bolonia y Salamanca!»!

Evidentemente el poeta "que Dios perdone» a que se alude ha muerto cuando Cervantes escribe esto; por su parte, el verso que se cita se localizó hace tiempo como perteneciente a un soneto atribuido a Liñán de Riaza que se conserva en un manuscrito de la Biblioteca Nacional de Madrid. Dicho soneto comienza:

\author{
"Yo Juan Bautista de Bivar, poeta \\ por la gracia de Ascanio solamente, \\ saltabanco mayor de todo Oriente, \\ laureado por Chipre y por Gaeta»².
}

${ }^{1}$ Cito por la ed. de Francisco Rico. Barcelona: Crítica-Instituto Cervantes, 1998, pp. $776-778$

${ }^{2}$ Ms. 3954, f. 346. El poema se dirige "Al jurado de Córdoba, Juan Rufo", fue publicado por Bonilla en sus Anales de literatura española. Madrid, 1904, págs. 111 y 112. Modernamente puede verse en la edición de las poesías de Pedro Liñán de Riaza con prólogo y notas de J. Randolph (Barcelona: Puvill, 1982), p. 84. Hay 
Según otra copia del soneto citado, a este poeta Bivar o Vivar "híçole laurear el cardenal Ascanio Colona en Alcalá»3. El poema nos habla sobre las buenas relaciones que el que sería cardenal Colona tenía con los ingenios que se dedicaban a las letras, cosa harto sabida también pues a este personaje se dedica la Galatea. Sin embargo no hay unanimidad en la atribución de este soneto a Liñán, en otros manuscritos aparece adjudicado al propio Vivar ${ }^{5}$, y en él se expresa que «las musas repentonas / te acusan del stupro que les haces ${ }^{6}$. Pero en cualquier caso, es claro que tanto la alusión de Cervantes como este poema de dudosa atribución se centran en la figura de un poeta, Juan Bautista de Vivar, repentista por antonomasia en la época que tratamos.

Ello nos sirve para volver a plantear la importancia de otro poeta de la generación de Cervantes, muy conocido en su tiempo y prácticamente olvidado en el nuestro (porque apenas nos había llegado rastro de su obra), por mucho que guardara estrecha relación con Lope y con el autor del Quijote. Porque si por algo puede ser conocido Vivar, sobre cuyo nombre ni siquiera se ponen de acuerdo los estudiosos modernos ${ }^{7}$, es por la relación con estos grandes nombres, junto a los cuales puede ser considerado uno de los creadores de esa corriente poética llamada Romancero nuevo; pero la suya parece una fama circunstancial, sólo vigente mientras vivía el poeta ${ }^{8}$.

un problema ecdótico también en este poema, porque según otros manuscritos el segundo verso sería "por la gracia del tiempo solamente» (ms. de la Biblioteca Colombina; y, además, ms. de la Riccardiana RI/8, razón por la cual algunos estudiosos lo han atribuido a Vivar.

${ }^{3}$ Ms. 3796 BNM, f. 346.

${ }^{4}$ Ed. cit. de J. B. Avalle-Arce, Madrid: Espasa-Calpe, 1987, p. 55.

${ }^{5}$ Ms. 33-180-6 de la Biblioteca Capitular de Sevilla, según Rodríguez Marín en su ed. del Viaje del Parnaso. Madrid, 1935, donde se introduce la variante importante en el segundo verso señalada en nota anterior, que permitiría considerar a Vivar como el autor. Pero, como advierte la ed. del Quijote de Francisco Rico (ed. cit., II, p. 497), si se prefiere la presente lectura el soneto de Liñán es una diatriba contra nuestro poeta y, de paso, contra el propio Rufo. La recóndita referencia a Ascanio Colona aparece ya en este segundo verso a propósito del nombre Gaeta, que se consideraba en la época derivado de Caieta, ama de Eneas, según escribe Virgilio en la Eneida. Trae la cita y recuerda todo ello Covarrubias s/v Gaeta, que hace derivar: «del nombre de la ama que crió a Eneas, y según algunos a Ascanio o a Creusa, por quanto quedó enterrada en aquel puerto" (Tesoro de la lengua castellana o española. Ed. Martín de Riquer. Barcelona: Alta Fulla, 1998).

${ }^{6} \mathrm{Op}$. cit., p. 84.

7 Es frecuente encontrarlo como Juan Bautista de Vivar o Bivar, y también sin el primero de los nombres.

${ }^{8}$ Lo hemos tratado por extenso en nuestro trabajo «Pedro Liñán, Juan Bautista de Vivar y don Luis de Vargas, tres poetas contemporáneos de Cervantes en torno al Romancero nuevo", en BRAE, LXXVII, 1997, pp. 99-125. Actualizo y completo aquí los datos que daba sobre Vivar en este trabajo. 
Precisamente en "El canto de Calíope», ese escaparate cervantino de la poesía de su tiempo que se incluye en La Galatea, cita el autor a muchos poetas de más o menos fama, pero justo después de referirse al Tajo y sus ingenios menciona a uno especialmente conocido como repentista (esto es, como improvisador), de la siguiente manera:

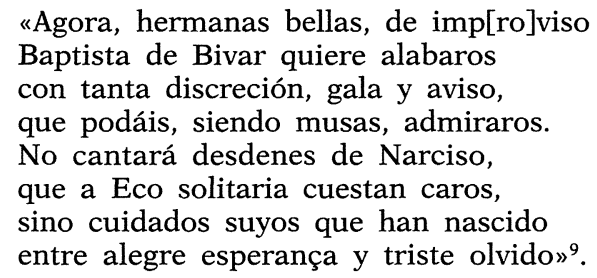

En estos versos alude Cervantes a algo que Vivar compartía con su amigo Lope, el intento de convertir en literatura sucesos de su propia vida. Poco se sabe de ésta, pero lo que conocemos nos permite aventurar que quizá fuera soldado, y parece seguro que fue laureado en Alcalá por el que sería cardenal Ascanio Colona, protector también de diversos ingenios de su tiempo, a quien cita Lope en La Dorotea como favorecedor de escritores durante su etapa de estudiante en Alcalá ${ }^{10}$. En cierto modo, da la impresión de ser un poeta áulico que busca siempre la sombra de los poderosos, porque lo encontramos no solo cerca de Ascanio Colona, también del Maestre de Montesa o del Almirante, que le solicita que le glose unos versos.

Pero existen sobre su persona más referencias literarias que nos ayudan a situarlo como poeta. Es de todos conocida la declaración que hace don Luis de Vargas en un proceso famosísimo contra Lope, su amigo, a quien se acusaba de haber compuesto unos libelos infamatorios contra la familia de Elena Osorio,

${ }^{9}$ La Galatea, ed. cit., p. 437 . El editor anota profusamente todo lo que tiene que ver con nuestro autor. En el texto, por errata, «imporviso".

10 «Dejando aparte su generosa grandeza, que como sol hermoso reverbera en el espejo de toda Italia, el ilustrísimo cardenal Ascanio Colona, su hermano, estudiando en Alcalá, favorecía los ingenios y estimaba mi ignorancia» (Ed. Edwin S. Morby. Madrid: Castalia, 1988, p. 452). Ascanio Colona (c1559-1608) era hijo del duque Marco Antonio Colonna, presente en Lepanto, estudió en Alcalá (se hace bachiller en 1577 y se licencia y dotora un año después) y Teología en Salamanca, donde pronuncio una Oratio en 1581; obtuvo el título de abad de Santa Sofía en 1578 (con tal título le designa Cervantes en la Galatea); llegaría a ser cardenal en 1586 y virrey de Aragón en 1602. Murió en 1608 (L. Astrana MARín, Vida ejemplar y heroica de Miguel de Cervantes, Madrid: Instituto Editorial Reus, III, pp. 446-448). 
en los que se incluía "un romance a modo de sátira» contra la joven y su familia. Dice el citado don Luis, hablando del romance, que:

«Es del estilo de quatro o cinco que solos lo podrán hacer: que podrá ser de Liñán y no está aquí; y de Cervantes, y no está aquí; pues mío no es, podrá ser de Vivar o de Lope de Vega ${ }^{11}$.

Más explícito es el propio Lope, en La Dorotea, cuando - después de enumerar los grandes poetas anteriores a él- hace recuento de los de su edad y escribe:

\begin{abstract}
«Francisco de Figueroa y Fernando de Herrera, que entrambos han merecido nombres de divinos; Pedro Padilla, el doctor Campuzano, López Maldonado, Miguel Cervantes, el jurado Rufos, el doctor Soto, don Alonso de Ercilla, Liñán de Riaza, don Luis de Vargas Manrique, don Francisco de la Cueva y el Licenciado Berrio, y este Lope de Vega que comienza agora.

LUD. ¿Esos son todos los que hay ahora en España?

CÉs. Déstos tengo noticia, y de Bautista de Vivar, monstro de naturaleza en decir versos de improviso con admirable impulso de las musas, y aquel furor poético que en su Platón divide Marsilio Ficino en cuatro partes $^{12}$.
\end{abstract}

La relación con Lope en esos momentos que recrea la obra es más que evidente, como ocurre también con Liñán o con don Luis de Vargas; el Fénix es amigo de nuestro poeta y de hecho le escoge como intelocutor de alguno de sus poemas más sentidos, como aquel que comienza "Vireno, aquel mi manso regalado», y que glosa el desprecio de Elena Osorio por haber atendido a un amante más adinerado ${ }^{13}$. Dicho poema se relaciona mucho con el primero de los que aquí reproducimos, atribuido al doctor Villegas.

Ese elenco de nombres famosos, entre los que se encuentra Lope o el autor del Quijote, pero también el muy conocido en su tiempo Pedro Liñán de Riaza, registra otros nombres menos sabidos como son los del propio Vargas, Juan Rufo o este de Vivar. Todos ellos participan de una corriente nueva en la poesía de la década de 1580 que es la del Romancero nuevo. Porque el Vivar mencionado por don Luis de Vargas no es otro que nuestro Juan

11 A. Tomillo y C. PÉrez Pastor, Proceso de Lope de Vega por libelos contra unos cómicos. Madrid: Fortanet, 1901, pp. 41-42.

${ }_{12}$ Ed. Edwin S. Morby, Madrid: Castalia, 1988, pp. 348-352.

13 J. DE EnTRAMABASAGUAS, Vivir y crear de Lope de Vega. Madrid: CSIC, 1946, p. 112. El poema se recoge en el llamado Cancionero antequerano, aunque no lo reproducen sus editores modernos (Cancionero antequerano recogido por los años de 1627 y 1628 por Ignacio de Toledo y Godoy y publicado por Dámaso Alonso y Rafael Ferreres. Madrid: CSIC, 1950). 
Bautista de Vivar, destacado siempre por su capacidad improvisatoria, algo muy alabado en un momento en que justas, academias y demás reuniones de ingenios demandaban esta habilidad especial para decir versos de repente, que a veces se convertían en una comedia.

Hay una evidente relación de ese grupo de ingenios con los poderosos mecenas de entonces que se dedican a proteger escritores y el nombre de Ascanio Colonna es uno de los más destacados. Seguramente en torno a sí reunió buen número de los poetas que aquí se mencionan: por un lado Luis Gálvez de Montalvo trabajaba a su servicio desde 1583 o 1584, quien tal vez aconsejó a Cervantes que dedicara su Galatea al prócer ${ }^{14}$; ayudó también a Juan Rufo, que le dedicó un poema a la muerte de su padre, y otro Andrés Rey Artieda en la edición de sus Discursos, epístolas $y$ epigramas de Artemidoro (1604). Muchos otros nombres girarían a su alrededor también. Pero no hay que olvidar otros nombres igualmente interesantes que pudieron cumplir esa función aglutinadora: el propio don Luis de Vargas Manrique (de quien más adelante hablaremos) o doña Agustina de Torres, madre de Catalina Zamudio, muy relacionada con Espinel y López Maldonado (que le dedica una elegía a la muerte de su madre en su Cancionero). Parece que en casa de esta última señora, casada con el ayuda de Cámara del Rey, Domingo Zuazo ${ }^{15}$, se celebraban veladas musicales a las que asistían el citado Espinel y otros.

Todos o casi todos participan en diversas reuniones y colaboran por ejemplo en libros que se publican por esos años, así en la citada Galatea, que cuenta con poemas laudatorios de Gálvez de Montalvo, Vargas Manrique y López Maldonado; también en el Cancionero (1586) de López Maldonado, donde se reúnen Cervantes, Lope, Liñán, Vivar, Rufo o Espinel, entre otros. Por otra parte, contribuye también a considerarlos como grupo el que aparezcan en poemas como "La casa de la Memoria» de Espinel ( $D i$ versas rimas, 1591) o en "El canto de Calíope» de la Galatea.

Parece que el grupo tuvo relación con Toledo y quizá también Vivar. Su amigo don Luis de Vargas era un hombre muy rico y gustaba de reunirse con otros poetas en su palacio toledano y en sus casas de Madrid después formando academia ${ }^{16}$. A esa vinculación circunstancial con la ciudad del Tajo nos lleva también la

\footnotetext{
${ }^{14}$ Astrana, Vida ejemplar...de Cervantes, III, p. 446.

${ }^{15}$ Ibíd., p. 238.

16 Véase nuestro trabajo «Pedro de Liñán, Juan Bautista de Vivar y don Luis de Vargas...», cit., pp. 102-104, donde damos cuenta de que en el palacio de los Vargas don Luis debió de formar una especie de academia, donde compartía sus ocios «con otros dos pastores llamados Varinto y Pavonio» (p. 103).
} 
lectura de su largo poema titulado «Burlas de Viuar» («Fregona de Biuar», en otra fuente) que comienza «En las orillas del Tajo», especie de ensalada poética que muestra líricamente el encuentro entre un caballero y una lavandera, tópico de la primitiva lírica tradicional ${ }^{17}$. Otros lugares con los que tal vez se pueda relacionar son el Betis y el Genil, como se aprecia en los poemas del manuscrito que reproduzco a continuación.

No es imposible que fecuentase el ambiente estudiantil de Salamanca, como también lo hicieran Góngora o Liñán, por los años en que este último asistía a las aulas. Algunos de los poemas que conocemos de nuestro repentista llevan la referencia de que fueron hechos en aquella ciudad en 1583, justo cuando Riselo se graduaba de bachiller ${ }^{18}$. Pero tampoco hay que olvidar que podría encontrarse en Alcalá de Henares, junto con Ascanio Colona en el tiempo en que este figuraba como estudiante en la Universidad, como se lee en La Dorotea.

Vivar parece que se procuró el mecenazgo del Maestre de Montesa (don Pedro Luis Garcerán de Borja, que cita Cervantes en su Galatea), según leemos en uno de los poemas que edito a continuación. Por lo que sabemos, este noble era también poeta, como observamos en las traducciones de Horacio que se recogen en el Cancionero de Pedro de Rojas ${ }^{19}$, y hombre acostumbrado a amparar escritores ${ }^{20}$ y acaso, como Colona, este maestre organizara algún tipo de reunión literaria donde convivieran los ingenios poéticos como Vivar y otros ${ }^{21}$. Los poemas del manuscrito de

${ }^{17}$ Publicado por R. Foulché-Delbosc, «Huit petits poémes», en $R H i$, IX (1902), págs. 282-85. El poema se recoge también en el manuscrito II / 973 de la Biblioteca de Palacio, donde lleva el encabezamiento «Fregona de Biuar, hecha el año de 1583 en Salamanca». Véase ahora Manuscrito Fuentesol, ed. de J. Labrador Herraiz, R. DiFranco y L. Bernard. Cleveland: Cleveland State University, 1997, p. 32, que localiza otra fuente que lo contiene

${ }^{18}$ Se trata del poema "Fregona de Vivar», citado arriba. Para los datos biográficos sobre Liñán puede consultarse el libro de RANDOLPH, cit., pág. 14.

19 Cancionero de Pedro de Rojas, ed. de José J. Labrador Herraiz, Ralph A. DiFranco y María T. Cacho. Cleveland: Cleveland State University, 1988, pp. 170182. El maestre es autor también de un soneto que obtiene la respuesta en otro por los mismos consonantes (poemas 59 y 60 de este Cancionero).

${ }^{20}$ Por ejemplo, Francisco Garrido de Villena le dedica su traducción del Orlando enamorado de Boyardo (Valencia: Ioan de Mey Flandro, 1555; otra ed. en Alcalá de Henares: Hernán Ramírez, 1577). También Pedro Roíz dedica su Libro de relojes solares al hijo del Maestre (Valencia: Pedro de Huete, 1575) y en el citado Cancionero de Pedro de Rojas quien copia los poemas del maestre añade además «mi señor» (loc. cit.).

${ }_{21}$ Poca información ofrece en este sentido una obra biográfica sobre nuestro personaje, que se debe a DIEgo SUÁREZ, la Historia del maestre último que fue de Montesa y de su hermano don Felipe de Borja. Madrid: Bibliófilos Españoles, 1889, tomo I. 
la Riccardiana que constituyen el objeto de estas páginas parecen sugerir tal cosa y los nombres de Catalina Zamudio, Vicenta Daroca, licenciado Sotomayor, doctor Villegas o el propio Vivar parecen estar unidos por alguna reunión de este tipo. Sabemos que era muy propio de las academias el componer poemas de repente que glosaran pies dificultosos, actividad en la que Vivar sin duda destacaría. Varios poemas del manuscrito citado glosan el mismo pie y eso quiere decir que debió de ser alguna prueba de ingenio a que se sometieron distintos compañeros de aventura.

Por lo que luego diremos, Vivar no debió de sobrepasar la última década del siglo XVI.

\section{OBRA POÉTICA}

Foulché-Delbosc da cuenta de dos poemas más atribuidos a Vivar, "Fílida ilustre, más que el sol hermosa» (pero publicado en El pastor de Fúlida de Gálvez, atribuido a Siralvo) y unas octavas a la vida militar que comienzan «A saber emplear la amada vida» ${ }^{22}$, de donde aventuramos la hipótesis de su empleo militar en una época en que Lepanto, las Azores o la Armada Invencible habían reunido a gran número de escritores, entre ellos casi todos los nombrados en la referencia de Vargas que arriba hemos reproducido. En este manuscrito que transcribo hay también un poema dedicado a la vida militar que, aunque no se pueda demostrar que le pertenece, camina en la misma dirección, incluso desarrolla el mismo tema y en el mismo tipo y número de estrofas.

Utilizó el sobrenombre poético de Vireno ${ }^{23}$, como se ve en el romance «Aquestas secretas selvas» y en otros textos que se editan a continuación, aunque no se nos escapa que tal nombre aparece frecuentemente en el ciclo ariostesco del romancero junto con la bella Olimpia y que hay que tener cuidado para no atribuirle a Vivar poemas que desarrollan dicho tema. Curiosamente en la comedia de Lope Los amores de Albanio e Ismenia aparece este nombre arcádico junto con otros como el de Ascanio. Dicha

${ }^{22}$ En su artículo «Los romancerillos de la Bibliothéque Ambrosienne», en Ibíd., XLV (1919), pp. 548 y 591. Recogemos el poema en la antología Armas y letras en el Siglo de Oro español, ed. de Víctor García de la Concha, con la colaboración de Abraham Madroñal y Mercedes Sánchez. Madrid: Ministerio de Defensa-Biblioteca Nacional, 1998, pp. 81-82.

${ }_{23}$ Creo que Quevedo le alude en un gracioso poema que dice: «Pues hubo pastor Belardo, / pues hubo pastor Vireno, / haya pastor Narigano: / guarde por cabras lenzuelos» (Obra poética. Ed. José Manuel Blecua, Madrid: Castalia, 19691971, II, p. 259). 
obra se localiza en el período en que Lope está en Alba gozando de la protección del Duque y se ha propuesto una fecha muy temprana para la misma (quizá 1591), todavía en vida de $\operatorname{Vivar}^{24}$. No sabemos si Vivar acompaña a Lope y otros ingenios con el Duque de Alba, pero es una hipótesis interesante ${ }^{25}$.

No cabe duda de que Vivar era poeta fácil y de que compuso también algunas obras dramáticas, pero solo nos ha llegado una muestra de su creación en este campo, una loa sacramental que se conserva en la Biblioteca de Palacio ${ }^{26}$. Porque era por su extraordinaria capacidad improvisatoria, como se ha dicho, por lo que Vivar era muy conocido; esa fama le llevaba a continuar poéticamente cualquier asunto, como el pie $Y$ no pudo decir $s u^{27}$, que glosa con una redondilla que comienza «Un mártir de Dios estava» 28 (de la cual se conocen algunas variantes, como la que glosa al pie Que no pudo acabar su y se inicia "Un mártir santo aguardaba», figura en un Cancionero sevillano $)^{29}$. Tal composición se hizo, según indica el manuscrito, en el Colegio de la Compañía de Jesús de Córdoba y tiene más posibilidades de pertenecer a nuestro poeta que al Conde de Salinas, a cuyo nombre se ha publicado $^{30}$.

Rodríguez Moñino le atribuye en su Catálogo de manuscritos de la Hispanic Sociey of America tres glosas más, que comienzan «Del arcediano de Coria», "Ya s' apareja Simeón» y "Virgen, la reyna sois de hermosura». Otra poesía suya, glosa del pie $Y$ sin bonete pues no, comienza "Bien puede en qualquier estado» y se halla en el conocido Cartapacio de Penagos ${ }^{31}$, en el cual se recoge también otra glosa al pie Trece sin llegar a trece, que comienza:

${ }^{24}$ S. Griswold Morley y C. Bruerton, Cronología de las comedias de Lope de Vega. Madrid: Gredos, 1968, pp. 76-77.

${ }^{25}$ Aunque no alude a Vivar, desarrolla este asunto José F. MONTESINOS, «Notas sobre algunas poesías de Lope de Vega", en RFE, XIII, 1926, pp. 143-152.

26 Véase Stefano ARATA: Los manuscritos teatrales (siglos XVI y XVII) de la Biblioteca de Palacio. Pisa, 1989, pág. 61. Ha sido publicada por este mismo autor y FAUSTA ANTONUCCI en su libro La enjambre mala soy yo y el dulce panal mi obra. Sevilla: Universidad de Sevilla, Universitat de València, UNED, 1996.

27 Véase sobre este mote el trabajo de ANTONIA María ORTIZ Ballesteros, "Y no pudo acabar su», en Edad de Oro, XII (1993), págs. 219 a 227, donde postula la posible autoría de Vivar y edita las distintas versiones de la glosa.

${ }_{28}^{2}$ Ms. 17557 de la B.N. de Madrid, f. 90.

${ }^{29}$ Manuscrito de la Hispanic Society of America, núm. XIV, f. 284 y v. Véase A. Rodríguez MoÑIno y M. BREY MARIÑo, Catálogo de los manuscritos poéticos castellanos de The Hispanic Society of America. New York, 1969.

${ }^{30}$ Véase Diego de Silva Y Mendoza, Conde DE Salinas, Antología poética 15641630. Ed. Trevor J. Dadson. Madrid, Visor, 1985.

${ }^{31}$ En el f. 156 (R. MENÉNDEZ PIDAL, "Cartapacios literarios salmantinos del siglo XVI», en BRAE, I, 1914, pág. 315). 
"Gocé de una niña bella»32. Otro poema suyo se halla en el Cancionero recopilado por D. Manuel de Faria, dedicado al Conde de Haro $^{33}$; se trata, como no puede ser menos, de una «glosa de Baptista de Vivar hecha de repente a petición del Almirante de Castilla» a Mueran, mueran, qu'es razón, que comienza "Huyendo las contingencias», que también aparece en otro manuscrito de la Biblioteca Nacional. Precisamente en ese mismo manuscrito se encuentran otras glosas suyas a los motes Si el amor muerte, que pudo; Buestro desdén a quien los ${ }^{34}$.

Además de las glosas, Vivar es también autor de poemas extensos de variado metro, como por ejemplo el larguísimo romance que se titula "Desafío y batalla entre el Amor y el Ynterés» (que comienza "Amor cuyo poderío») y que se encuentra en un manuscrito de la Biblioteca Nacional ${ }^{35}$. Conocemos también otros tres romances atribuidos a Vivar, que se contienen en el Ramillete de flores, qvarta, quinta y sexta parte recopilado por Pedro de Flores en Lisboa (1593), que se inician "Por el ancho mar de España», "Aquestas secretas selvas» y «Un pastor pobre y umilde» ${ }^{36}$. Igualmente el manuscrito II / 973 de la Biblioteca de Palacio le atribuye el romance que comienza "Por los jardines de Chipre» ${ }^{37}$, tantas veces recogido como anónimo en otros manuscritos y que se ha atribuido tentativamente a Lope por estudiosos modernos ${ }^{38}$. A ellos

${ }^{32}$ Manuscrito 11/1581(1) de la Biblioteca de Palacio Real. La reproduzco en mi trabajo "Pedro Liñán, Juan Bautista de Vivar y don Luis de Vargas, cit., p. 124.

${ }^{33}$ Ms. 3992 de la B. N. de Madrid, f. 96 y vo. También en el ms. 4152 de la misma biblioteca, ff. 107-108. Cf. ARTHUR L. F. AsKINS, «The Cancionero Manuel de Faria and ms. 4152 of the BNM», en Luso Brazilian Review, 6, 1969, pp. 22-43.

${ }^{34} \mathrm{El}$ cit. 4152 , ff. $108-109 \mathrm{v}^{\circ}$. Ambos poemas comienzan con los versos «La muerte y amor han pedido" y "Con regalos y regaños". Pienso que es muy posible que sea suya la siguiente composición en el mismo manuscrito, que se introduce así: "Muriéndose Bautista, dixo al Santíssimo Viático, que le llebaron, de repente: Si para hazer discuento»(f. 110v). Revelaría el buen humor del poeta hasta en sus postrimerías.

${ }_{35}$ Mazamorra de varias composturas, Ms. 3909 BNM. Se trata de un cancionero copiado con letra del siglo XVIII, pero que "recoge poemas de autores de la segunda mitad del XVI». El poema, atribuido a "Bautista de Bivar», ocupa los folios $416 \mathrm{v}^{\circ}$ a $430 \mathrm{v}^{\circ}$ y escoge como forma métrica el romance, aunque se intercalan formas distintas, como se describe en el Catálogo de Manuscritos de la Biblioteca Nacional con poesía en castellano de los siglos XVI y XVII (Madrid: Arco Libros, 19932003, 6 vols.). Este largo poema presenta una batalla entre el Amor y el Interés, que vence el segundo a fuerza de comprar a los partidarios del primero, y está muy en consonancia con el poema de Cervantes cuyo verso nos sirve de título en el presente trabajo.

${ }^{36}$ Ff. 32, 33 y 38v", respectivamente.

37 Ms. II / 973, f. 383.

${ }^{38}$ Entre ellos un buen especialista como José F. Montesinos. Véase lo que dicen al respecto J. LABRADOR, R. DIFRANCo y L. BERnARD en su edición del Manuscrito 
tal vez habría que sumar algunos de los que edito a continuación, particularmente el que empieza «De todas las de Genil» (núm. 77).

No fue muy amigo de colaborar en preliminares de libros ajenos, pero en el Jardín divino hecho en el año de Xpo. de 1604 de Juan de Varayz y Vera aparece un poema suyo a la Magdalena, que se inicia "Madalena, ¿qué aguardáis?»39. Dicho poema ya había parecido en los preliminares de la Conversión de la Magdalena (1588) de Malón de Chaide y en la de Juan Bru de la Madalena: Obras espirituales... en el día y fiesta de Santa María Madalena $(1591)^{40}$; igualmente en el libro de Miguel de Luna La verdadera historia del rey don Rodrigo (1592) figuran unas redondillas de Vivar que comienzan "Aquí lector podrás». Salvo el último, los libros anteriores tienen contenido religioso, algo a lo que la musa de Vivar también se prestó en varias ocasiones. Así encontramos una composición suya en el llamado Cancionero de Fuenmayor, florilegio sevillano de principios de siglo XVII, en el que aparece una "Glosa de Vivar a lo divino" al verso Uno es uno, que no lo entiende ninguno y que comienza "Es Dios substancia infalible» ${ }^{41}$.

Como he dicho, es probable que su fecha de muerte haya que situarla poco después de 1592, si no en ese año mismo. A ello nos lleva el hecho de que no se halle citado en el Viaje del Parnaso, donde sin duda lo hubiera recogido su amigo Cervantes de seguir vivo; tampoco Lope se acordaba ya de él, cuando en 1630 publica el Laurel de Apolo, en el que sí cita a otros poetas amigos muertos mucho tiempo antes, como es el caso del compañero de ambos, don Luis de Vargas Manrique, que muere probablemente en 1591 de viaje a Italia.

En sus poemas canta Vivar los desengaños amorosos, casi siempre al bien perdido, a la ausencia de la amada o al recuerdo de un pasado mejor, que invariablemente contrapone con la amargura del presente. Otras veces es la vida militar la que se convierte en tema de sus poesías ("Octavas a la vida militar», "Por el ancho mar de España», o la que edito ahora «Ha sido siempre el bélico exercicio», núm. 26), en ellas invita a la guerra a un joven, como también hará en su loa sacramental, anteponiendo la profesión de las armas a la de las letras, incluso despreciando estas últimas en favor de las primeras. En el segundo de los poemas aludidos muestra con singular maestría el comportamiento de una nave

\footnotetext{
Fuentesol, cit., p. 57-58, donde localizan buen número de cancioneros que también contienen este romance.

${ }^{39}$ También contenida en el ms. 4154 de la BNM, ff. $38 v^{\circ}-39 v^{\circ}$.

${ }^{40}$ Roma, 1591, ff. 68 a 71.

${ }^{41}$ ANTONIO RodRígueZ MoÑIno, "Tres cancioneros manuscritos», en Ábaco, II, 1969, p. 178.
} 
y sus ocupantes en tiempo de tormenta. Aunque el tema religioso le tentó en diversas ocasiones, es sin duda el jocoso-burlesco el que domina en los versos de este repentista, capaz de componerlos con los pies más inverosímiles, a veces sacados de un cantarcillo tradicional o de un poema culto como la Araucana.

El manuscrito del que hablo a continuación ofrece una buena prueba de ello, porque parece una reunión de composiciones que pertenecen o giran en torno a nuestro poeta para mostrar sus habilidades.

\section{El Ms. 3096 RI/7 DE LA BIBLIOTECA RicCARDIANA DE FloRENCIA}

Nuevos poemas se vienen hoy a sumar a los que conocíamos de este famoso repentista, precisamente los que se contienen en el Cancionero manuscrito 3096 de la Riccardiana. Se trata de un códice bien curioso, que su catalogadora describe así:

«Foliación moderna. El último sin foliar. 2 hojas de guarda delante y dos detrás y en medio la antigua encuadernación, en pergamino, con 1 hoja de guarda delante y otra detrás con anotaciones. Restaurado. Contiene poemas en castellano y en italiano, pero estos escritos con muchos españolismos. 2 manos. 1 de ellas escribe el f. $20 \mathrm{r}$ y la hoja 66, el nombre de Baptista de Vivar en el núm. 31, los núms. 34 y 35 y añade los núms. 39, 41, 43 y 45, intercalándolos en los espacios libres de las glosas de Juan Bautista de Vivar. Encuadernación moderna en pergamino, con correíllas. $165 \times 110 \mathrm{~mm} .{ }^{42}$.

Me interesa especialmente el hecho de que esté escrito por dos manos diferentes, una de las cuales intercala el nombre y la glosas de Vivar en determinadas partes del manuscrito. Contiene también varios textos en prosa, en castellano, y otros poemas en italiano que parecen no tener que ver con los poetas de que tratamos aquí y que no transcribo a continuación. Se trata de un texto copiado por un italiano, con las particularidades gráficas que ello conlleva y que intento reflejar en mi transcripción. Abundan en él los poemas de subido contenido erótico, incluso sin paliativos en la expresión. También las partes en prosa caminan por ese tipo de literatura, en ocasiones. Hay textos en italiano primero, después vienen los escritos en castellano, y junto a ellos textos en prosa que tienen que ver con cuentecillos de la época, muy subidos de tono y con franca libertad en la expresión ${ }^{43}$.

${ }^{42}$ María Teresa Cacho, Manuscritos hispánicos en las bibliotecas de Florencia, II. Firenze: Alinea Editrice, 2001, p. 328.

${ }^{43}$ Por cuanto aparecen algunos como el siguiente: «A un gran carajo lee este 
Alterna este cancionero los poemas escritos en metros italianos (sonetos, octavas, silvas, etc.) con otros de métrica castellana (villancicos, redondillas, romances...). Hay también una curiosa mezcolanza de poemas de carácter culto con otros de tipo tradicional, algunos de los cuales son los que presentan contenido erótico o tratan temas típicos de este tipo de lírica (como las canciones de despedida, de ronda o las letras para cantar). Se corresponden estos poemas con los cuentos de carácter tradicional que se recogen en el mismo códice, también en castellano.

En lo que toca a la fecha de copia del códice, encuentro una referencia clara que tal vez pueda señalar el momento de copia del manuscrito: «Dalla natiuita de Christo fino al anno corente sono anni 1567», pero también es muy probable que este apunte en realidad se limite a copiar otro que no tenga que ver con los versos que aquí se transcriben, porque encuentro glosado algún que otro verso de la primera parte de la Araucana (1569), una referencia más que probable al Viaje de Sannio de Juan de la Cueva (1585), y en otro momento se escribe en el mismo manuscrito la fecha de 1613, que tal vez corresponda al tiempo de un poseedor posterior del cartapacio que fue adicionando en él diferentes cosas.

Importa mucho también considerar qué otros nombres aparecen en el códice, sin duda acompañantes de Vivar en alguna reunión de ingenios. Algunos son desconocidos o casi desconocidos como poetas, es el caso de doña Vicenta Daroca, del doctor Villegas $^{44}$ o del licenciado Sotomayor ${ }^{45}$; otros no lo son tanto y nos han dejado algún rastro lírico: doña Catalina Zamudio está presente con sendos poemas laudatorios en las Diversas rimas (1591) de Espinel o en la La hermosura de Angélica, de Lope $(1602)^{46}$. En

sobrescrito: A una dama le dixo un caballero: "Mirá, que no se os caiga el birgo», y ella le respondió que la mañana se le clavaron con un clavo tan largo».

${ }^{44}$ Encuentro un doctor Villegas que firma la "Suma de corrección», del libro de PEDRO DE LUJÁN, Coloquios matrimoniales (Alcalá de Henares: Sebastián Martínez, 1577), pero parece más probable que se trate del doctor Villegas de Guevara, del que se sospecha que hubiera escrito versos satíricos contra el doctor Velázquez en 1588 (A. Tomillo y C. Pérez PAStoR, Proceso de Lope de Vega, cit., pp. 58 y 170). Por supuesto, otros nombres coinciden con el apellido de este poeta, pero ninguno ostenta el grado de doctor: por un lado está el ANTONIO DE VILlEGAS, autor del Inventario (1565); por otro, el famoso ESTEBAN MANUEL DE VILlEGAS, autor de las Eróticas y todavía existe un Sancho de Villegas, autor de un villancico en el ms. 617 de la Biblioteca de Palacio.

${ }_{45}$ Tal vez el licenciado Juan de Sotomayor, "vecino de Alcaraz», que contribuye con dos sonetos a la Nueva filosofía de la naturaleza del hombre, de Miguel SABUCO (Madrid, Pedro de Madrigal, 1587).

${ }^{46}$ Espinel en su "Casa de la memoria», de las Diversas rimas, no nombra a doña Catalina, pero sí escribe unos versos a Clarinda (ed. cit., p. 120), que se 
cualquier caso parece que son, junto a Vivar, los poetas que participan en una academia o reunión ocasional (o fija) de ingenios ${ }^{47}$. Lo que resulta indudable es que este cancionero recoge con especial dedicación los versos de este último y es particularmente rico en glosas de repente, muchas de las cuales están atribuidas a él. Acaso buena parte de los poemas no atribuidos también le pertenezcan, aunque no podemos asegurarlo. En otras ocasiones, Vivar solo aparece aludido, como destinatario poético de otros versos de compañeros de aventura como Catalina Zamudio (núm. 3) o el doctor Villegas (núm. 1).

Es evidente que no podemos asegurar que los poemas que aquí aparecen como anónimos pertenezcan a nuestro poeta, de hecho tenemos indicios de autoría de otros autores, pero sí da la impresión que algunos de ellos se le pueden atribuir, especialmente algunas de esas glosas del principio. Por otra parte, alguna referencia biográfica podemos extraer de este conjunto de versos. En uno de los poemas alguien escribe a Vivar que «en la orilla de Genil / gozas tus verdes años» (núm. 46), que puede aludir a una estancia granadina del poeta que tal vez confirmaría el romance que empieza «De todas las de Genil» (núm. 77), acaso atribuible al numen de Vivar. Pero más importancia tiene, según mi opinión, una alusión a los poetas sevillanos que parece se quiere ceñir especialmente a Juan de la Cueva, por cuanto cita uno de sus versos del Viaje de Sannio (1585). En efecto, en la «Epístola al maestre de Montesa» (núm. 31) escribe Vivar:

«Tú que a ser mi mecenas te dispones,

a pesar de la gente que pretende

que no hay Mecenas porque no hay Marones».

El último verso, como indico en la nota correspondiente, recuerda una estrofa del poema citado de Juan de la Cueva y puede ser un episodio más de la pugna entre la poesía andaluza y la

identifica hoy con una poetisa peruana. Doña Catalina Zamudio era hija de doña Agustina de Torres, que había formado en Salamanca una especie de reunión musical a la que también acudía Espinel (G. HALEY, Obras completas, I., de Vicente Epinel. Málaga: Diputación Provincial, 1994, p. 49). Era hermana de la también poetisa doña Ana Zuazo. Según los documentos publicados por Pérez Pastor, estuvo casada con Francisco Ruiz de Ezcaray pero, sobre todo, unida sentimentalmente a don Félix Arias Girón, también muy amigo de Lope. Murió en 1630 (Memorias de la Real Academia Española, X, 1911, pp. 305-306).

47 Sabemos que al menos hay dos en Madrid que ronden esas fechas: la Imitatoria y la de los Humildes, la primera está relacionada con Rufo y en otro lugar hemos aventurado que pudo presidirla don Luis de Vargas; a la segunda pertenecía, entre otros, Leonardo Argensola (W. F. KING, Prosa novelística y academias literarias en el siglo XVII. Madrid: RAE, 1963, pp. 28-30). 
castellana, que tanto desarrollo tendrá en los años que nos ocupan $\mathrm{y}$ en fechas posteriores. Vivar reconoce ser castellano justamente en un verso de este cancionero que editamos (poema núm. 30).

Es muy interesante la relación que presenta nuestro códice con un cartapacio salmantino, concretamente con el denominado Cuaderno K del Colegio Mayor de Cuenca de aquella Universidad. En dicho cuaderno no solo se copia un poema, también presente en nuestro códice con ligeras variantes, sino que se dirige otro a Ascanio Colonna, donde se habla de "Clarinda" (muy presente también en nuestro códice), del mecenazgo del primero y del sentimiento hacia él de la segunda por su partida a la guerra. En otro poema se vuelve a hablar del sentimiento de Clarinda y aún en otro de Dardanio (en nuestro códice aparece Dardania). Todos estos datos juntos hablan de la indudable cercanía de estas dos recopilaciones poéticas, solo que en la del Colegio de Cuenca todos estos poemas se atribuyen a Gaspar Gil Polo, autor de la Diana enamorada, mientras que en nuestro códice uno de ellos se adjudica a Catalina Zamudio. Las fechas de copia son parecidas: cerca de 1564 para el códice salmantino; a partir de 1567 para el nuestro. Hay que señalar también que al menos dos poemarios de la Biblioteca de Palacio guardan alguna relación con los autores que aquí aparecen o con algunos de los poemas que encontramos en este manuscrito de la Riccardiana: el Cartapacio de Penagos y el ms. 973 de dicha Biblioteca.

A diferencia de estos que citamos, el presente códice parece dispuesto para mostrar las capacidades poéticas de Juan Bautista de Vivar, no es solo que responda por los mismos consonantes en sendos sonetos a otros que le dirigen el doctor Villegas o doña Catalina Zamudio, es también la abundancia de glosas de pies imposibles que se recogen y se le atribuyen y algunos otros poemas en que aparece su nombre, bien como autor, bien como destinatario de los mismos. En definitiva, un conjunto de poemas de Vivar o muy relacionados con él, que creemos que merece la pena que se añada a la larga lista de recopilaciones poéticas de los siglos XVI y XVII y que seguramente leyeron $\mathrm{u}$ oyeron Cervantes $\mathrm{y}$ Lope y con ellos cimentaron la extraordinaria fama de este poeta en su tiempo. Entre la alegre esperanza y el triste olvido, que escribe Cervantes, se mueven los poemas de Vivar que se recogen en este cancionero florentino y precisamente es la esperanza de que este olvido no sea tan absoluto lo que nos mueve a dar a conocer estos versos desiguales, pero interesantes para el devenir de la poesía española. 


\section{EDICIÓN ${ }^{48}$}

Dadas las circunstancias particulares de la copia y la fecha de la misma, he decidido respetar escrupulosamente las grafías del códice (pero unifico el uso de $u$ para vocal y $v / b$ para consonante; lo mismo en el caso de $i / y$, y desarrollo la $r$ simple como $r$, en los casos en que tiene este valor), actualizando solo la puntuación, acentuación y mayúsculas del mismo. Actualizo también todo lo que afecta a la unión y separación de palabras, según el uso actual, pero manteniendo las amalgamas típicas (deste, dél, etc.). En el caso de amalgamas como nel me he permitido su desarrollo indicándolo con apóstrofo (' $n$ el). Desarrollo también los timbres de nasalidad (en $n$ o $m$, según convenga) y la abreviatura $q=q u e$, sin dejar constancia de ello. Mantengo la $s$ - líquida también.

Como he dicho, se trata de un texto copiado por un italiano, que muchas veces no entiende lo que tiene que copiar, de ahí que haya parte de algunos versos que se dejan en blanco (y que señalo con tres puntos entre corchetes). En ocasiones el copista no sabe cómo reproducir determinado sonido castellano y utiliza grafías aproximadas de su lengua; mantengo también en estos casos dichas grafías (giamas por jamás, goia tal vez por joya).

Transcribo los poemas en castellano del texto, que se encuentran en los folios $5,20 \mathrm{v}^{\circ}$ a 66 , salto tanto los poemas escritos en italiano como los textos en prosa, ya estén escritos en esta lengua o en castellano. Omito dar la localización concreta de cada poema, porque el códice está perfectamente descrito en la obra citada de Cacho.

${ }^{48}$ Tengo que dejar constancia de mi gratitud para con Antonio Carreria, por lo mucho que ha contribuido con su lectura a mejorar la transcripción del texto. 


\section{APÉNDICE}

\section{Del doctor Villegas a ViVAR. SONETO ${ }^{49}$}

Vireno, aquella blanda, hermosa yedra que al muro de mi pecho viste asida en cuyos laços tuve entretenida de mi firmeza la costante piedra;

5 o, ingrata planta, ya de mí se arredra y a un tosco roble la verás señida, sin oja y flor que desagradezida de mi firmesa la costante piedra ${ }^{50}$.

No pensé yo, pastor, que el firme ñudo que fue apretado con tan fuertes laços romper pudiera aquel injusto ziego;

mas, aunque marchitar mi yedra pudo y desasir mi cuello de sus braços, inposible será matar mi fuego.

2. DE VIRENO, RESPUESTA.

Ya yo me acuerdo ver tu amada yedra al firme muro de tu pecho asida y con tu dulce canto entretenida, que ablanda y muebe un coraçón de piedra.

5 Agora sé que huye e que se arredra la que a tu frente vi, pastor, señida, que desa fiera desagradezida quien más la sirve sólo aquesto medra

${ }^{49}$ Véase arriba lo dicho sobre la identificación de este doctor Villegas. El poema recuerda mucho a un soneto atribuido a Lope que comienza "Vireno, aquel mi manso regalado", que edita J. DE ENTRAMBASAGUAS, Vivir y crear de Lope de Vega, cit., p. 112. Ambos poemas escogen a Vivar como interlocutor y desarrollan la imagen de un elemento de la naturaleza (una planta, un animal) que se desase de su antiguo protector para darse a otro nuevo, provocando el despecho del primero.

${ }^{50}$ En el ms., por error, se repite el verso cuarto, cuando en realidad deberíamos encontrar un verso acabado en "medra». 
Mas pues ella rompió tan fuerte ñudo, no quieras tú de nuebo atar los lazos, que para todos tiene ojos el ziego.

$\mathrm{Y}$ aquel que marchitar tu yedra pudo y desasir tu cuello de sus braços podrá también matar tu imenso fuego. Fin

3. De doña Catalina Samudio. Soneto ${ }^{51}$

Si la ponsoña fiera del engaño tan sin remedio al más amigo offende, si su secreta llama tanto enciende que no ay alma sigura de su daño,

5 y si mi vida con dolor estraño el falso daño deshacer pretende, sin duda mi contento y gloria pende del fiel amigo, dulce desengaño,

a quien mil gracias doy que me consiente que goce de mis hojos, vida y alma antes que engaño la vitoria lleve;

que andaba ya mi mal tan diligente que uviera de alma y vida y ojos palma si no fuera del tiempo el parto breve.

\section{De VIRENo a ClaRinda EN RESPUESTA. SONETO}

Engá[ña]ste ${ }^{52}$, Clarinda, que el engaño jamás al verdadero amante hofende

\footnotetext{
${ }^{51}$ Con muy pocas variantes y como "Soneto del desengaño», se recoge en el Cartapacio poético del Colegio de Cuenca (Ed. J. Forradellas Figueras. Salamanca: Diputación de Salamanca, 1986, p. 254). Para el editor la autoría de Gaspar Gil Polo "parece bastante segura" (p. 51) y su fecha, muy cercana a la edición de la Diana enamorada (1564). El uso de la correlación, precisamente en este soneto es un indicio más de autoría, según su opinión (p. 529). Ahora bien, en realidad lo único que parece que se atribuye a este autor es el primer poema del cartapacio y no cabe duda de que el soneto su utiliza justamente en este contexto del códice que editamos y que tiene incluso una respuesta de Vivar "por los mismos consonantes» en otra prueba de ingenio poético. Puede ser que doña Catalina Zamudio copie un texto anterior de Gil Polo, pero puede ser también (y parece más probable) que sea su verdadera autora.

${ }_{52}$ Cacho lee «Dígoste». Reconstruyo la palabra.
} 
cuando en la dulce llama que se enciende sujeta el coraçón libre a su daño.

$5 \quad$ Si el alma adora su dolor estraño y con engaño vive, ¿qué pretende quien dice que su vida y gloria pende del cruel enemigo, desengaño?

Maldito el desengaño que consiente que se pierdan los ojos, vida e alma sin que dellos amor victoria lleve;

y bien aya amador tan diligente que lleba de alma y vida y ojos palma sin aguardar del tiempo el parto breve.

[Hay una hoja arrancada de la que tan solo se lee la palabra «Son». No consta atribución en los poemas siguientes]:

\section{GLOSA}

Este perro tiene cúyo ${ }^{53}$.

Bien es que el perro proboque a todos a pïedad y que ninguno le toque, pues saben tiene amistad con San Lázaro y San Roque. $\mathrm{Y}$ aunque parece que es suyo, señor maestro, concluyo que no puede ser de tantos porque teniendo dos santos este perro tiene cúyo.

${ }^{53}$ Mote y glosa se copian también en el ms. II/1581(2) de la Biblioteca de Palacio, precedido de lo siguiente: «Estando en una conversación entró un perrillo y començaron le todos ha dar de coçes y dijo uno de los que estaban allý, que era maestro". Un poco más adelante en el mismo ms. de esta Biblioteca se recoge otra glosa que dice lo siguiente: "Bienes que espero proboque/ a todos a piedad», que es la misma que la presente y que tiene al final firma y rúbrica de don Diego Sarmiento. 
6. GLOSA

No puede dejar de eser ${ }^{54}$.

Firme estaré en mi dolor y en mi pena no fingida, y soy tan firme amador que antes faltará la bida

5 que a mí me falte el hamor. Yo e de amar y padecer y e de morir y querer por llevar de amor la palma, porque lo que sea 'n el alma no puede dejar de eser.

\section{GlosA}

Quando pienso bivir muero.

Mil veses deseo morir y para más mal se alarga la bida, porque el bivir es una pesada carga

5 que no se puede sufrir. Que ansí si la muerte spero muero porque morir quiero y no quiere el ado esquivo.

Quando pienso morir bivo,

8. GLOSA

No deve de ser por bien ${ }^{55}$.

Quien se descuida no hama, descuido en amor no cabe; $\mathrm{se}^{56}$ Amor enciende la llama tan solo sabe el que sabe

${ }^{54}$ Mantengo el italianismo eser. Acaso utiliza aquí un verso de Castillejo: «Aunque dél esté goloso, / No puede dexar de ser / Como ciervo temeroso" (Ed. J. Domínguez Bordona. Madrid: La Lectura, 1928, II, p. 267).

55 Verso que se recoge en el Romancero de Pedro Padilla: "Yo bien sé Pascual á quién / preguntó Menga por tí. / No deue de ser por bien, / que ya no ay bien para mi» (Madrid: Bibliófilos Españoles, 1880, p. 512).

${ }^{56}$ En lugar de si condicional, como aparecerá más adelante. 
5 apagalla con su dama.

Voluntad tan desigual, tanto desqüido y desdén ni dar de pasión señal, $\operatorname{taratar}^{57}$ el amor tan mal no deve de ser por bien

9. GLOSA

Su gusto es verme sin él.

Amor de malicia lleno empezó a acerme favor; no lo tuve yo por bueno, que debajo de la flor

5 encubre el falso el veneno. Entre el cucillo e cordel se me muestra el traidor fiel por mostrarse más ingiusto y en la mitad de mi gus[to] su gusto es verme sin él.

10. GLOSA

Quanto más tarde más berde ${ }^{58}$.

El firme amador que alcansa de su dama algún favor no tema tiempo ho mudansa, que mientras ture el amor a de turar la esperança; mas si de visa la pierde no es bien su dama se acuerde d'esperança que no aguarda porque suele ser, si tarda,

10 cuanto más tarde más berde.

\footnotetext{
${ }^{57}$ Es decir, tratar.

${ }^{58}$ Se recoge también en el ms. 4117 , f. $178 \mathrm{v}^{\circ}$, de la BNM, como anónimo, con variantes: "Quanto más tarda, más verde». Glosa. «El amador que no alcança...».
} 
11. GLOSA

Buscome la muerte en vos ${ }^{59}$

Porque staba en vuestra cumbre gozando del paraýso lo que esta alma tanto quiso hizo muerte su costumbre.

5 Quitome el bien de inproviso y me dicio ${ }^{60}$ ansí: "¿Sois vos? Muy contento estáis, por Dios». $\mathrm{Y}$ derriba mi vitoria, pero como busca gloria

10 buscome la muerte en vos.

12. GLOSA

Que si la bida me enoja ${ }^{61}$.

Cansado ya de sufrir mi congoja dura y fiera, mil veses deseo el morir porque estoy ya de manera

5 que [he] aborrecido el bivir. Si de tan fiera congoxa el coraçón no se afloxa y yo ya siento acabarme, no ay para qué preguntarme que si la vida me enoja.

13. GLOSA

\section{$Y \sin$ bonete pues $n^{62}$.}

Sin ser hijo de San Pedro puede salvarse qualquiera

\footnotetext{
${ }^{59}$ En un cancionero manuscrito de la Biblioteca del Escorial se recoge este mote: "Buscóme la muerte en vos/ porque supo que viuía / en vuestra uida la mía", que se desarrolla luego en seis estrofas que no tienen que ver con la presente (Julián Zarco, "Un cancionero bilingüe manuscrito de la Biblioteca de El Escorial», en Religión y Cultura, 24, 1933, pp. 406-449, el poema en la p. 440).

${ }^{60} \mathrm{El}$ copista quiere transcribir el indefinido dijo.

${ }^{61}$ Se trata de un verso del cantarcillo de Joaquín Romero de Cepeda, que recoge Cervantes un tanto modificado en El rufián dichoso: «Muerte y vida me dan pena; / no sé qué remedio escoja: / que si la vida me enoja, / tampoco la muerte es buena» (Teatro completo. Ed. Florencio Sevilla Arroyo y Antonio Rey Hazas. Alcalá de Henares: Centro de Estudios Cervantinos, 1995, p. 424).

${ }^{62}$ Véase la composición núm. 38.
} 
y florecer como el cedro, que para todo [...]

5 Si en el bien [...].

Aga lo que debo yo

y lo que Dios me mandó

y sierta tendré mi silla,

que santos ay sin capilla

10 $y$ sin bonete ipues no?

14. GLOSA

Porque tu cabello cuyo ${ }^{63}$

Mil inpreças veo traer, señora, de tus cabellos, mil cuyos suelen tener; mas no das alma con ellos

5 porque no sabes querer.

$Y$ pues que quedan en calma quantos se nombran por tuyos y tú a naide das la palma, ¿si no tiene cúyo el alma, por qué tu cabello cúyo?

15. GLOSA

Ojos me queréis hazer.

Sola vos podéis hazerme, sola podéis redimirme $\mathrm{y}$ de flaco azerme firme $\mathrm{y}$ de perdido ponerme

5 donde salvo me refirme. $\mathrm{Si}\langle\mathrm{n}\rangle$ tan rico puedo ser con solo vuestro querer y quedar tan satisfecho vida, pues me avéis desecho; ojos ¿mé queréis hacer?

${ }^{63}$ Mote y glosa se recogen en el ms. 4117 de la BNM, f. 177: Pie: «Porque tu cavello cuyos», que se glosa: "Mill impresas veo traer». 
16. GLOSA

Al amor porque es poner ${ }^{64}$.

$\mathrm{Al}$ encendido amador que de veras está siego ardiendo en llamas de amor, no curéis matar su fuego,

5 que le encenderéis mejor. Porque quando empiesa [a] arder la llama del bien querer un infierno duro enseña, por do no es bien quitar leña

10 al amor, porque es poner.

17. GlosA

Plega a Dios que sí se ensaya.

Un día que yo trataba amores con mi pastora me dixo que la engañaba y que mi lengua ensayava

5 para dezirlos a Flora. "Si se ensaya», respondí, "al cielo ruego que caya un rayo y la parta aquí». Y ella dixo: "No sea ansí,

10 plega a Dios, que sí se ensaya».

18. GLOSA

Porque [es] con tu fiesta el suelo.

Con tu fiesta, Virgin pura,

el suelo en cielo has tornado, que un suelo el cielo figura más claro que las estrellas y de mayor hermosura. Ninguno ponga recelo

${ }^{64}$ Este mote se glosa también, con ligeras variantes en el Jardín poético, ms. s. XVIII (A. RodrígueZ MoÑIno-M. BREY MARIÑo, Catálogo de los manuscritos poéticos... de The Hispanic Society of America. New York: The Hispanic Society of America, 1965, I, p. 321) y dos veces en el ms. 4117 de la BNM, ff. $102 v^{\circ}$ y 200. No se cita autor en ninguno de los casos. 
en si es el suelo cielo

ni ya el cielo dónde está

ni quál el cielo será

10 porque es con tu fiesta el suelo.

19. GLosA

Se tiene en menos que quando

Dos hombres vi razonar ${ }^{65}$

y el uno al hotro dezía

que con él se a de matar,

que él mismo señale el día

5 y las armas y el lugar.

Y el competitor echando

a su gran valor el sello,

armas y lugar nombrando

dice que no por aquello

10 se tiene en menos que quando.

20. GLOSA

Que si en sant [a] os igualó

Marta, aunque de vos se canta tan santa solicitud, también Madalena es santa

y quien coge y se levanta

5 aspira a mayor virtud;

que si es verdad que peccó, caída se levantó

a la santidad que veis,

ansí que no preguntéis

10

que si en santa os igualó.

21. GLOSA

En medio de las altas aguas unas.

Pues estáis en las aguas sabullidas,

hermosas nimphas, nunca estáis patentes;

salid a remediar nuestras heridas

mostrad, siquiera, [las] ermos[as $]^{66}$ frentes,

\footnotetext{
${ }^{65}$ No entiendo bien esta palabra. $\mathrm{M}^{\mathrm{a}}$ Teresa Cacho lee rahonar.

${ }^{66}$ No puedo leer lo que pone en este pasaje, acaso las hermosas, pero no es más que una conjetura.
} 
5 salid, seréis de nos requeridas $\mathrm{y}$ admiraréis al cielo y a las gentes, pues sois en ríos, fuentes y lagunas en medio de las altas aguas, unas.

22. GlosA

La bida el que pudiere la asigure ${ }^{67}$.

Es inposible asigurar la bida, pues en la bida no ay cosa sigura; mas dar color a la berdad fingida téngolo por gran muestra de cordura, que la reputación siendo perdida ni tienpo ni razón lo sana o cura, pues porque libre eternamente dure la bida el que pudiere la asigure.

23. GLOSA

Los hojos bueltos que del negro dellos ${ }^{68}$.

Si puede amor con flechas de tus hojos, quando los tienes bueltos que no miran, herir tan fuerte el alma y sus despojos si[n] errar giamás lanse en quantos tiran, 5 dexando el corazón lleno de enoxos de ver que allá 'n el cielo se retiran. Si de allí puede tanto y son tan bellos los hojos bueltos, ¿qué del negro dellos?

\footnotetext{
${ }^{67}$ Es un verso de la Araucana, primera parte, el que se glosa ahora: "Viendo que aprovechar no le podía, / dice: 'De mí, señores, nadie cure, / la vida el que pudiere la asegure'» (ed. de Isaías Lerner. Madrid: Cátedra, 1993, p. 188).

${ }^{68}$ Primer verso de un poema que se recoge en el ms. II/973 de la Biblioteca de Palacio: "Los ojos vueltos, que del negro dellos / muy poco o casi nada paresçía» (con leve variante en el Cartapacio de Penagos, de la misma Biblioteca, y en el ms. $\mathrm{NC} / 6$ de la Biblioteca Nacional de Florencia dentro de las obras de Fray Benito. Véase Cacho, op. cit., I, p. 96). Existe también soneto erótico recogido entre otras fuentes en un cancionero de Ravena y varios de la BNM; en el ms. 20.620 se dice además: "Soneto del Vicentino que acabó a lo humano y comenzó a lo divino» (véase su ed. en Poesía erótica del Siglo de Oro, recopil. de P. Alzieu, R. Jammes e Y. Lissorgues. Barcelona: Crítica, 1984, pp. 19-20). Dicho soneto fue tan famoso que incluso se conoce una glosa del mismo (ibíd., pp. 21-25). Se recoge igualmente en un ms. de la BN de Florencia, en otro de Ravena y en el Cancionero de Joan López.
} 
24. GLOSA

En la cruz que sí, que no ${ }^{69}$.

Aviendo crucificado tres honbres, si es honbre Dios, el de en medio uno a dudado y sobr' ello an apostado

5 la goia de entre los dos. «Que es Dios» Dimas replicó; Gestas que es hombre afirmó. $\mathrm{Y}$ anbos la berdad porfían,

10 en la cruz que sí, que no.

25. A UN ALFILER QUE PICÓ UN DEDO DE UNA DAMA

Vuestros alfileres son muy diestros, aunque inhumanos pues antes que a vuestras manos toparon mi coraçón.

5 Si vuestra sangre vertieron, la de mis braços helaron, que sus gotas se tornaron flechas que mi pecho abrieron.

10

Si es que el amor enbió mirando mi mal a dansa ese alfiler en vengansa, aun esa no quiero yo,

que bien sé que os tiene ansí de enbidioso e[l] ciego dios

15 no por vengarse de vos, mas por vengarse de mí.

Alfileres tan crueles que en la bida hazen suerte llámense flechas de muerte en figura de alfileres.

\footnotetext{
${ }^{69}$ Se recogen el mote y la glosa en el ms. II/1581 (2) de la Biblioteca de Palacio, "por mano de Gondomar" (Catálogo de la Real Biblioteca, XI. Madrid: Patrimonio Nacional, 1995, p. 157).
} 
Aunque de rigor tu mano la disculpa es conocida pues dando en bos la herida de mi alma es todo el daño.

25 Al fin vi verter, señora, la sangre de vuestras venas estando de ravia llenas las del que os quiere y adora. creyendo qu' era triaca, mas es veneno que saca la vida y alma por ella.

Sangre herida en instrumento si en mi alma verdadera

35 toca y de acesa manera bien podéis jusgar si os siento.

Si el enojo es contra mí, buelva por mí el rigor más a la berdad mejor

40 me mataréis desde aý.

Si en sangre de más [---]ina se ponen telas de arañas daré las de mis entrañas, si balen por medicina.

$45 \quad$ Y si inportare licor del mismo cielo descienda y si a de ponerse benda ofresca la suya hamor.

Fin.

\section{A LA BIDA SOLDADESCA. ESTANTIAS ${ }^{70}$}

A sido siempre el béllico exercitio de señores y príncipes honrrado, es enemigo capital del bitio pues no ay ociosidad en canpo armado,

5 la tierra amiga, el cielo l'es propitio al que tracta la bida del soldado

\footnotetext{
70 Tanto por el tema como por la métrica y el número de estrofas coincide este poema con que se atribuye a Vivar titulado "Octavas a la vida militar», que se recoge en un ms. y fue publicado por Foulché-Delbosc (1919). Podría tratarse también de un tema de academia desarrollado por varios poetas. Véase nuestra antología Armas y letras en el Siglo de Oro español, cit., pp. 81-82.
} 
y ansí muriendo peleando salta desta bida terrestre a la más alta.

Es una fragua donde el mundo apura valientes y covardes coraçones porque la guerra a veces disfigura los que en la paz se pintan por leones. $\mathrm{Y}$ aquel de quien el mundo no se cura da muestras de tan altas intenciones

15 que es premio escaso para tanta gloria que la fama eterniçe su memoria.

Es un ábito noble, es un bestido que al príncipe, al marqués, al duque, al conde, al cavallero, al bien y mal naçido,

20 a todos igualmente corresponde, llévase quada qual su merecido. $\mathrm{Ni}$ el premio ni el castigo se l'esconde, consigo lleva cada qual su suerte pendiente de su braso flaco o fuerte.

25 Bive el soldado entre las armas fieras como las cosas graves en su centro en dar asaltos, derribar banderas y en las batallas uno y hotro enqüentro ganar fuertes, castillos y trincheras,

30 hazer la encamiçada y el rencuentro $\mathrm{y}$ al fin, qual salamandra, bive en guerra donde aumenta su honra el hocio atierra.

Guárdaçe la amistad, honra y giusticia, tanto que si en el mundo hisiere falta 35 todas tres se hallarán en la militia, que dellas biste y dellos tres se esmalta. Hase en pie el auditor prompta gustitia, amigo con amig[o] giamás falta: si algún agrabio se recibe ho haze con armas y valor se satisfase.

Pues si las leyes y armas van unidas, las armas con las leyes son guardadas, las leyes con las armas defendidas, las unas con las hotras respetadas.

45 Reinos, ciudades, bienes, hijos, bidas quedan en pas y gerra aseguradas, asientan armas y letras en el suelo, como Cástor y Póllux 'n el cielo. Fin 
27. GLOSA

De quién, sino de mí puedo quexarme

Si el tiempo y la ocasión me a demostrado la bariedad de aquesta humana bida y si no al bien seguro 'n el estado que más el apetito y gusto pida.

5 Si el más justo y leal es engañado desta fábula y máscara finjida y si pudiendo no suppe guardarme, ¿de quién, sino de mí puedo quexarme?

28. GLOSA

\section{Tomada [e]stá la posada ${ }^{72}$}

Este bien en que me beo es quien solo me asigura que nunca podrá bentura burlarse de mi deseo. Y pues este solo agrada benir hotro no conbiene, porque le diçe si biene: "Tomada [e]stá la posada».

Quando en la libertad toma el amor poçeción no queda dispoxición para axena boluntad; él izo llana la entrada para quien más la mereçe

15 y si hotro güésped se hofrece tomada [e]stá la posada.

Solo bivirá en mi pecho el que más que al alma quiero, que si en tienpo no es $\langle\mathrm{el}\rangle$ primero

20 es muy mejor en derecho.

\footnotetext{
${ }^{71}$ Otra vez se glosa un verso de La Araucana, primera parte: «¿De quién sino de mí puedo quejarme / pues todo por mi mano se ha guiado?» (ed. cit., p. 371).

${ }^{72}$ Es un verso famoso que puede tomarse del romancero morisco: «Tarde llegó Abindarráez, / tomada está la posada» (Romancero historiado, de LUCAS RoDRíguez, ed. Agustín Durán, Madrid: Rivadeneira,1851, I, p. 58). Lope lo usa en El maestro de danzar: "Tarde, amor, hemos venido; / tomada está la posada» y Valdivielso en sus Doce autos sacramentales y dos comedias divinas (1622).
} 
La fuerça tiene hobligado a perpetuo vasallaxe y escrito en el homenaxe: «Tomada [e]stá la posada».

25 Quién podrá venir jiamás que con mil bienes yguale al menor que tiene y bale quien bale conmigo más. Todo es sifra, todo es nada,

30 todo es poco para mí, todo se buelba que aquí tomada [e]stá la posada

En gentilesa y balor ¿quién llegará a su caudal?, en discreción sin ygual, en calidad sin mejor. Amor traigo ${ }^{73}$ la enbaxada, raçón aprobó este bien, mirad por quién y con quién

40 tomada [e]stá la posada.

Todo fue tarde conmigo y esto solo fue tenprano, bentura puso su mano y el tienpo fue buen amigo.

45 Fue la tiñebla apartada, mostró el cielo su contento; Amor yzo el aposento [y] yo entregé la posada.

29. GLOSA

La más hermosa que Dios ${ }^{74}$

En una ermosa unión de damas vi proponer

\footnotetext{
${ }^{73}$ Acaso quiere transcribir así el indefinido trajo.

${ }^{74}$ Este verso se glosa también en el ms. 22.028 de la BNM en dos poemas distintos. (Véase Poesías de fray Melchor de la Serna y otros poetas del siglo XVI, ed. de J. Labrador Herraiz, R. DiFranco y L. Bernard. Málaga: Universidad de Málaga, 2001, p. 328.) Según la Tabla de los principios, aparece también en un ms. de la Riccardiana, el 3358, en el Cancionero de Fuenmayor (como primer verso que glosa un pie distinto), en el de Jacinto López, en el de Morán y en el Toledano, ms. 17689 de la BNM. Igualmente aparece en el ms. 4117, f. $203 \mathrm{v}^{\circ}$, de la BNM, pero con glosa diferente. Consta también en las poesías de Salinas, aunque con glosa diferente (Poesías humanas. Ed. Henry Bonneville. Madrid: Castalia, 1988, p. 290, donde se señala que sería tema de una justa).
} 
una subida qüestión escrita en solo un ringlón:

5 «Quién es el de mayor ser». De entre'llas salieron dos a quien Dios más gracia dio diçiendo: "Deçildo bos». Y de las dos respondió

10 la más hermosa que Dios

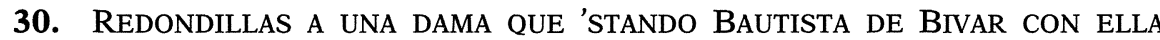
LLEGARON TRES POBRES A PEDILLE LIMOSNA

Limosna que ansí enriquese bien es que un honbre la pida y si da en cambio la vida con más raçón la mereçe.

5 Desde agora certifico que no ay bien que no me sobre, pues a un tienpo triste y pobre me vi alegre y rico; pero ciendo vos tan franca querellar de vos me quiero, que a todos dais a dinero y a mí me dais una blanca.

A tres pobres estendistes con un dinero la mano

15 y a mí como castellano sola una blanca me distes.

Mas tanto esta blanca vale, tales Indias en sí encierra, que no ay tesoro en la tierra que a esta blanca se le iguale.

Vengan mis duelos doblados, que aunque el dinero me manca, no pienso dar esta blanca por quinientos mil ducados;

25 que amor que a sido tan franco, aunque el coraçón me arranca, hará que con esta blanca no haga mi suerte en blanco.

¿Quién de tan rica pobresa podrá ya estimar el horo 
ni azer montón de tesoro

de una tan pobre riquesa?

Nuevo blasón y renonbre, Amor, por esto te doy pues con una blanca soy el más rico de los hombres.

Bien aventurada sinta, no solo te he de guardar pero pienso conservar

40 lo que tu color me pinta.

Amor ¿por ello qué dieras?, ¿de qué pecho no triunfaras, si para arroxar tus xaras desta cuerda el arco izieras?

$45 \quad$ Pero no dudo que a sido de tus bellos ojos benda, porque no ay fuego que ençienda como ella a mí me [ha encendido $]^{75}$.

Ya con ella no reçela quien se pretende enbarcar, pues para pasar el mar me podrá servir de vela.

Que quando están más airados

55 dando en ella quedarán amorosos y tenplados.

Su dueño será $\langle a\rangle$ mi estrella, no ay tormenta que temer, que mal se podrá perder quien se guiare por ella

$\mathrm{Y}$ si en las aguas cayere, tu çinta, que a todo igualas, como a Uliçes la de Palas me llevará a do quiziere.

Fin

\footnotetext{
${ }^{75}$ En el ms., por atracción de la forma verbal anterior, enciende.
} 


\section{Epístola al maestre de Montesa ${ }^{76}$ DE BAPta. DE Bibar}

Ecelso monte, cuya altiva frente ${ }^{77}$

de laurel adornada y circuida

no teme del gran Giove el rayo ardiente,

pues eres el albergue y acogida

5 de todos los que huyen de la muerte

y de algunos que huyen de la bida,

mi pobre coraçón quiero hofrecerte, que de la muerte y de la bida huye. Tan grande es la incostancia de mi suerte.

10 Pues huigo de la muerte que destruye las sciencias nobles, y por hotra parte de aquella vida que ingora[n] $\mathrm{cia}^{78}$ arguye.

Tú que tienes guardado el baluarte $\mathrm{e}[\mathrm{n}]$ cuyos elevados torreones tremo[ló $]^{79}$ de Minerva el estandarte;

tú que a cer mi mecenas te dispones, a pesar de la gente que pretende que no ay Meçenas porque no ay Marones $^{80}$;

entre tus verdes faldas me defiende, donde por ser contino primavera ni enoja el frío ni el calor hofende.

${ }^{76}$ Como se dice en la introducción, acaso don Pedro Luis Garcerán de Borja, maestre de Montesa, citado como "sin segundo", en la Galatea, autor de algún poema, como el publicado en las Obras de Pedro Laynez (véase J. B. AVALLE-ARCE, en su ed. de la Galatea, cit., p. 455) y de otros en un ms. de la Hispanic Society of America (A. Rodríguez MoÑino-MARÍA BREY, Catálogo de manuscritos, I, p. 137).

${ }^{77}$ Este verso parece copiarlo Leonardo de Argensola en el inicio de un soneto que se encabeza de la siguiente manera: «Escrivióse cuando el año 1592 el rey don Felipe el segundo, nuestro señor, acabó de celebrar cortes a los aragoneses en Tarazona, que yaze en la falda del Moncayo, con quien habla el soneto, cuyo assunto es alavar el rigor i clemencia de que su Magestad havía usado en aquella sazón para el bien público". Su primer verso varía en muy poco este de Vivar: «Excelso monte, cuya frente altiva» (Rimas. Ed. José Manuel Blecua. Zaragoza: CSIC, 1950, p. 209). Probablemente tanto Vivar como Argensola, pero más el primero, tengan en cuenta el poema de Aldana dedicado al monte de Alverna, cuyos dos primeros versos dicen: "Dichoso monte en cuya altiva frente, / de pinos y altas hayas coronada» (Ed. José Lara Garrido. Madrid: Cátedra, 1985, p. 355).

${ }^{78}$ En el ms. ignoracia.

${ }^{79}$ En el ms. tremo.

${ }^{80}$ Creo que Vivar está recordando aquí unos versos del Viaje de Sannio de JUAN DE LA CUEVA: "Ya no hay Virgilios porque no ay Mecenas, / i como no ay Mecenas no ay Virgilios» (Ed. José Cebrián. Madrid: Miraguano, 1990, p. 60). 
¡Quién fuera tan dichoso que pudiera volverse un árbol tuyo y qué sabrosas fructas aunque silvestres produciera!

25 Pero no son las musas tan dichosas que siempre mueren giunto a sus deseos ${ }^{81}$ como las engañadas mariposas.

Yo al tienpo, quando logre mis empleos, haré que escuche el reino de la aurora tus infinitas gloria y trofeos,

pues de la giente que 'n el Betis mora será primero oída y celebrada mi ronca bos por tu ocazió[n] se honora

35 contra la boluntad del tiempo abaro de quien es persegida y acosada,

porque el ingenio peregrino y raro que fuera en hotro tiempo ennoblecido con estatuas de mármoles de Paro

40 agora está 'n el río del holvido solo porque aborreçe la riqueça, siendo de la riquesa aborrecido.

Pero pues por tu cumbre y asperesa como serpiente atravesado puedo

45 desnudarme el bestido de pobresa,

no temo a la fortuna y tengo miedo que con esta partida que çe hofrece del bien que me hofrecí me desheredo;

mas tu poder que a tantos engrandeçe

50 si a cada qual se parte el bien que digo conforme a la ventura que mereçe

a poco me parece que le hobligo, pues sabe el mundo lo que yo meresco y pésame de dar tan buen testigo

55 al fin por ser ingenio que caresco de tu valor a tu valor divino como reciente víctima me ofresco

${ }^{81}$ Se tacha antes el verso: «donde por ser contino primavera». 
a ti me umillo y postro, a ti me inclino y adoro la grandeça de tu cumbre,

60 donde como en espejo cristalino miró primero el sol en su hermosura. Fin

32.

Tristesa, si a un alma triste ${ }^{82}$ queréis tener compañía, no te apartes de la mía bivirás donde naciste.

Glosa

Un alma a do la tristesa tiene su ordinario asiento con tal rigor y aspereça que a echo de su tormento

5 hábito y naturalesa aunque es tan dura porfía espera, suffre y resiste mil pesares noche y día jiamás se verná alegría

10 tristesa se a un alma triste.

Esta por mi triste suerte se a echo tan natural con el mal rabioso y fuerte que a qualquier plaçer convierte en su ponsoña mortal.

De mí naçe, en mí se cría y pues tú, tristesa, eres echura del halma mía ve conmigo $\mathrm{se}^{83}$ a do fueres quieres tener compañía

En mi alma la ternás tan semejante a la tuya que en ti misma dudarás si eres mía por ser suia

25 o por ser yo tuyo más. $\mathrm{Y}$ pues vais por una vía ella sin ti y tú sin ella

${ }^{82}$ El pie se recoge también el Cartapacio de Morán de la Estrella, de la Biblioteca de Palacio Real y en el Cancionero de JUAN DE PERAZA (Biblioteca Wolffenbüttel). También en el Cartapacio de Ramiro Cid y en el II/1580(2), de la misma Biblioteca, con glosas diferentes.

${ }^{83}$ Como en otras ocasiones, se quiere transcribir el condicional si. 
giamás ternéys compañía por el bien tuyo y el della no te apartes de la mía.

En mí serás recebida del modo que tú quisieres $\mathrm{y}$ en tanto estremo tenida que quando acaso murieres

35 ternás quien te dé hotra vida. Si de lugar tan triste pierdes tu naturalesa y esta solo en mí consiste

40 bivirás donde nasciste. Fin

33. SONETO DEL LiCENCIAdo DE SOTTOMAYOR A UNA DAMA Llamada SOLIZA

Si al sol is a buscar, busca a Solisa, sola tan sola como el sol es solo, tan clara que la luz del mismo Apollo debajo de sus pies la pone y pisa.

5 Aviso que al más alto aviso avisa, beldad no vista de uno al otro polo, su semejante ser dezime a dolo, que casi al celestial se sube y frisa.

Solisa, si tu vista desparziendo

$10 \mathrm{y}$ con tu claro viso sin segundo eclipsas nuestro sol y a ti lo humillas,

solo, Solisa, de tu ser entiendo que solo te crió Dios en el mundo para mostrar en ti sus maravillas.

34. A LA MiSMA. SONETO. SOTOMAYOR

No más, Solisa, no, baste lo hecho, baste matar no más que ya estoy muerto, que si en amar yo hize desconcierto con dar la vida doy el satisfecho.

5 Que el caçador no busca más provecho después que al coraçón dio tiro çierto, ni el navegante más que alegre puerto ni amor busca más bien que tierno pecho. 
Que si al contraste del amor vacila

10 el pecho enamorado no mereçe del mismo amor la dulçe paz tranquila.

Por eso el mío, que su fe engrandeçe (rabie Caribdis, amenaze Cilla),

al mar se arroja y al amor se offreçe.

35. SONETO

Lo largo es falso, es corcho lo más bello, lo ancho casi todo es verdugado, lo hondo todo está falsificado, rota la nema y aun quitado el sello.

5 Oro de candelero es lo del cuello, falsa la joya y falso lo bordado, el jubón al vobiscum muy onrado mas al per omnia no querría [i] vello. los alfileres y el color vendido, lo blanco, el rebotín y la espinaca!

En fin, embustes de çien mill maneras, tanto que entre lo çierto y lo fingido apenas hallarás a doña Urraca.

\section{VERSOS DIFFICULTOSOS GLOSADOS POR JUAN BAUTISTA DE BIVAR}

36.

Cortó la parca el hilo y despojado ${ }^{84}$.

\section{Glosa}

Dios herido el costado con la llaga que fue remedio universal del suelo pues ella sola fue bastante paga a tanta culpa y tanto desconsuelo.

$5 \quad$ Y porque más al padre satisfaga manos y pies clavados sin consuelo, quedó en la cruz, quando desamparado cortó la parca el hilo y despojado.

${ }^{84}$ Recuerda un verso de la Diana de Montemayor: «Cortó la parca el hilo muy de presto» (Ed. Asunción Rallo. Madrid: Cátedra, 1991, p. 415). 
37. Obra duro jamás fue en ella oído ${ }^{85}$.

Glosa

Su gran torre Nembroth edificava y era la confusión y bozería tal que lo que uno a otro demandava sin orden y al revés se lo traía.

5 Gritos Nembroth al pueblo ciego dava, mas Dios que no lo oyesen permitía y en quanto aquella (jo loco mal regido!) obra duró jamás fue en ella oído.

38.

$Y \sin$ bonete pues $n 0^{86}$.

Glosa

Bien puede en qualquier estado un buen christiano salvarse, que el cielo no le a obligado como a clérigo a ordenarse,

5 ni a ser claustral encerrado. Cumpla los preçetos yo que la Iglesia me ordenó y tendré en el çielo silla, que sanctos ay sin capilla $y$ sin bonete ¿pues no?

39.

Fortuna, tinta y ventana

Glosa

A una ventana me puse do a mi dama contemplando fortuna me fue ayudando pues con la pluma dispuse

5 lo que amor me iva enseñando.

Ella oyó de buena gana la pasión fiera inhumana que mis versos le dixeron, porque me favorecieron fortuna, tinta y ventana

${ }^{85}$ También se recoge con leves variantes en el ms. 17556 de la BNM. Véase la ed. de RITA GoldBERG, Poesías barias y recreación de buenos ingenios. Madrid: José Porrúa Turanzas, 1984, II, p. 373. La citada editora señala que «no se han encontrado otros textos" del poema (ibíd., p. 531).

${ }^{86}$ Este mote, con esta misma glosa, figura en el ms. II/1581(2) de la Biblioteca de Palacio Real a nombre de Vivar. 
40.

Hiciera la tabla arder ${ }^{87}$

Glosa

En una tabla esculpida con un semblante sereno está la que me da vida, triaca de mi veneno,

5 bálsamo de mi herida. $\mathrm{Y}$ allí aun no me dexan ver estos pintados despojos que a bivos suelen vencer, que el alquitrán de mis ojos

41.

Lágrimas que no pudieron ${ }^{88}$

Glosa

Lloren los enamorados ${ }^{89}$ que lágrimas suelen dar alivio a muchos cuidados y ablandarse con llorar

5 los coraçones elados.

Lágrimas piedras movieron, las fieras enternecieron y aun la nieve encenderán. ¿Lágrimas qué no podrán, lágrimas qué no pudieron?

42.

En agua conbertido ${ }^{90}$ sería si el fuego que mi pecho enflama las lágrimas no hubiesse consumido y todo fuera llama;

${ }^{87}$ Pie y glosa se recogen también en el ms. 4117, f. 177, de la BNM, como anónimo.

${ }^{88}$ Es un verso del cantarcillo: «Lágrimas que no pudieron / tanta dureza ablandar / yo las bolberé a la mar, / pues que de la mar salieron", que se recoge en la sexta parte del Ramillete de flores (M. FRENK, Nuevo corpus de la antigua lírica, núm. 2598). El Padre Cigorondo lo glosa de otra manera en el ms. CCXIII de la HSA (vid. A. Rodríguez MoÑINo-BREY, Catálogo, II, p. 423). Se recoge igualmente el pie (pero con glosa distinta) en el ms. 4117 de la BNM, f. $203 v^{\circ}$.

${ }_{89}$ Con este verso empieza un decir del Marqués de Santillana (Poesía lírica. Ed. Á. Gómez Moreno; Maximilian P. Kerkhof. Barcelona: Planeta, 1988, p. 34).

${ }_{90}$ Se recoge igualmente como anónimo en el Cancionero dirigido a la monja doña Beatriz, RI/6 de la Riccardiana de Florencia (CACHO, op. cit, II, p. 324). 
5 si el llanto que he vertido no huviera el vivo fuego detenido deshiciérame luego el largo llanto en llanto, el fuego en fuego; más mientras cada qual quiere mi muerte

10 me dan luchando vida. ¡Ho dura suerte!

Ay celos, rabia cruda salida del infierno [a] atormentarme con amor conjurados a matarme; como destemplas yelo

15 el calor del amor y de la vida; ai ponsoña bebida de voluntad, ai mar de desconsuelo; suéltete deste velo los celos, rabia cruda

20 de esperança y plaçer alma desnuda.

43. Béçame, niña mía, que tus beços ${ }^{91}$ me son más que el panal dulce y sabroso y estence, niña, nuestros labios presos produciendo deleites amorosos,

5 que bien podremos, aunque más travieços, goçar callando trançes tan gustoços. Estén nuestras dos bocas aprietadas como las conchas de la mar pegadas.

44.

[Amar la noche, aborrecer el día].

Noche serena, alegre, clara y pura ${ }^{92}$ que con la sombra de tu turbio manto mi soberano sol de hermosura da lus al alma y pone freno a llanto, tiende las alas de tiñebla oscura, no apresures tu curso, o noche, tanto ¿no saves que es el fin de mi porfía amar la noche, aborrecer el día?

O noche para mí más dulce y clara que 'l claro sol que nace del oriente cubre del cielo la ermosa casa

${ }^{91}$ Acaso recuerde al tradicional «Bésame, moza» (FRENK, núm. 1673A).

${ }^{92}$ Una "Canción de don Alonso de Fonseca" se inicia de la siguiente manera: «Noche serena y fría / que a sombra de tu manto nos socorres» (ms. RI/3 de la Riccardiana de Florencia. Véase CACHO, op. cit., II, p. 317). 
en quanto veo mi sol resplandeciente, no seas, noche, a mi ruego avara mientras vive mi vivo raio ardiente, que ar[á $]^{93}$ con su lumbre el alma mía amar la noche y aborrecer el día.

45.

\section{Crecieron y crecerán}

sin fin en el fin que tienen

los que en mi mar se sostienen.

Porque luego siego Amor en virando ${ }^{94}$ su valor con un súbito regalo de bueno me izo malo

5 y de leal traydor. Despedí la covardía dando suelta a la maldad sin mirar lo que devía porque el seso y libertad el amor me lo tenía.

46.

No fíes de tu alegría ${ }^{95}$,

Vireno, mira por ti, que también me dejó a mí la que yo tuve algún día.

5 Si en la orilla de Genil gozas de tus verdes años, mira bien no sean engaños, que [en] las mujeres ay mil.

$47^{96}$.

Ninguno desespere por verçe persegido en esta bida pues sabe que si muere su honra no cumplida

5 el alma sin remedio va perdida.

${ }_{93}$ En el original are.

${ }^{94}$ No está clara la lectura.

${ }_{95}$ Recuerda al tradicional «En los tus amores, / carillo, no fíes, / cata que no llores / lo que agora ríes" (FRENK, núm. 2008 bis). Es una manera de iniciar el poema que se puede encontrar en otros, como el que empieza: "Nadie fíe en alegría» (ms. NC/7 de la Biblioteca Nacional de Florencia), que glosa Diego Hurtado de Mendoza (Poesía completa. Ed. José Ignacio Díez Fernández. Barcelona: Planeta, 1989, pp. 211-212).

${ }_{96}$ Se recogen igualmente en el ms. II/1580(2) de la Biblioteca de Palacio, como anónimas. 
Los ojos en el cielo

el hombre ha de poner y este camino

le lleva sin recelo

al otro que es dibino

10 do no puede faltar plaser contino.

Allí las esperanças

en gloria volverán gosando dellas

y sin temer mudanças

avrá reposo en ellas

15 con gran seguridad de no perdellas.

Peresca la locura,

el alma puede más que el cuerpo humano

pues busca desventura

quien piensa ser ufano

20 en el mundo cruel, traidor, tirano.

El ánimo prudente

abraça la prudencia y se desvía

del daño y acidente

que el apetito guía

25 y toma la virtud por compañía.

Pues luego deste sueño

morir es lo de acá breve y prestado,

sugieto a qualquier muerte

como un sueño pesado

30 que da para engañar qualquier pecado.

48.

O fealdad, sepoltura

de miserable dolor,

enemiga del amor,

de su descanso y holgura;

5 yo no vea

en mi muerte cosa fea,

que fealdad según siento

es ver la muerte 'n el biento

vestida de su librea.

49.

La cruesa y ermosura ${ }^{97}$

dos contrarias cosas son,

97 Parece guardar relación con el poema que se inicia «Con tan perfecta hermosura / dos contrarias cosas son" (ms. de la Biblioteca Nacional de Florencia. Cacho, op. cit, I, p. 35) 
por lo qual niega razón permetas mi desventura en pago de mi afición. $\mathrm{Y}$ assí digo que deseches la cruesa, pues cruessa y gentilesa no es bien que more contigo.

10 Si me llamas, ¿por qué llamas me queman desta manera? Responde, flor de las damas, ¿por qué permites que muera y en mi vengança te enflamas?

15 ¡Ay de mí, que en triste fuego me quemo y con saber que es ansí no lo precio ni lo temo!

No permitas la vengansa deste que tienes rendido ni quieras mostrar holbido a quien con tanta esperança a tus manos es venido. Mas yo quiero

25 lo que tu voluntad quiere: que quien muere como muero entiéndase que no muere.

No me quieras despreciar, porque moriré más presto;

30 echa la culpa a tu gesto, el qual me pudo forçar con su ser puro y honesto. $\mathrm{Y}$ ansí siento dolor en ser desdeñado,

35 que 'l coraçón dezamado luego pierde el sufrimiento.

Buelve los ojos, señora, un poco más regalados a mis ancias y qüidados,

40 que no es bien que toda hora los quieras tener ayrados.

Que 'sa ira es mi muerte muy tenprana, siendo tú tan inhumana

45 a quien llorando sospira.

Si tienes por mejor suerte mi morir, yo moriré; 
más ¿qué ganas en mi muerte?

Tanto que es firme la fe

50 que tuve y tengo con verte,

de manera

que munchas veces me arguyo

cómo muero siendo tuyo

o tú permites que muera.

50. Sin mugeres el mundo y el bien dellas sería confuzión, guerra y fortuna, quedando como el cielo sin estrellas, faltando lo demás, que es sol y luna.

5 Son flores de la bida, alegres, bellas, que merece mil mundos sola una en todo lo demás que está criado por sola su bondad, virtud y estado.

Sugétanse ${ }^{98}$ los fieros animales

10 al regalado amor y sus asañas, que huyen deste amor hombres bestiales que tienen muy perverças las entrañas. Pues venid, amadores muy leales, entended las victorias, fuerças, mañas de aqueste nuestro ser ermoso y fuerte por quien es dulce vida qualquier muerte.

Florecen en los prados nuevas flores, resplandescen las aguas de las fuentes y las aves cantando den clamores

20 conbidando a dulçura a todas gentes. $\mathrm{Y}$ todos los penados amadores descançen sin sentir más acidentes contenplando en amor y sus victorias, pues ay de su valor tantas ystorias.

51. Un anillo muy preciado con una piedra estremada queda mejor encastada, sy de negro es esmaltado.

5 Y la tierra morena que dentro encierra

la simiente 'n el verano es mejor y da más grano contra el invierno e su guerra.

\footnotetext{
${ }^{98}$ En el original sugentase.
} 
52.

Que me da contento solo el pensamiento.

Una ermosa dama sierto me enamora, porque no es persona que gruñe en la cama.

$5 \quad \mathrm{Y}$ aquesta me enflama el amoros[o] yntento que me da [contento solo el pensamiento].

Quítole la toca

10 de la cara tierna, álsole la pierna blanca y amorosa y con esta cosa toco el elemento.

15 Que me da contento [solo el pensamiento].

Tómole las manos, aprieto los dedos, porque no 'stén quedos mis intentos vanos; y con ser profanos ago en un momento que me da [contento solo el pensamiento].

25 Con letras graciosas uso de mil tretas, tócole las tettas blanca[s] y amorosas. $\mathrm{Y}$ con estas cosas

30 anda el elemento que me da contento [solo el pensamiento].

Ágole cosquillas con galana risa,

35 pruevo las servillas, also las faldillas asia la camiça; le busco el sarmiento, que me da [contento

40 solo el pensamiento]. 
$\mathrm{Al}$ salir la cosa

de aquel dulce cabo pareçe que sabe más que miel sabrosa;

45 sin tan dulce cosa aquesto que qüento que me da [contento solo el pensamiento].

Con las piernas blancas

50 las ingles esparce, porque se desaze por mostrarlas francas; parecen las ancas molino de viento

55 Que me da [contento solo el pensamiento].

Quando al tranze llego deste mi desmaio

60 en un bivo fuego; en bolviendo luego mui gran gusto s[i]ento, que me da [contento solo el pensamiento].

53. De La SRa. Vinçenta Daroca

Insine reina Quiopatria muy gran llanto asía sobre el cuerpo de Anttonio, que muerto entre sí tenía:

5 ¡Ay, ay, ay alma mía!

Sus cabellos muy dorados sobre sus honbros tendía, torciendo sus blancas manos su lindo rostro iría

$10 i A y,[$ ay, ay] alma [mía]!

Pártese para el sepulcro donde su Anttonio yazía, mil abraços l'está dando, que estar bibo parecía.

$15 i$ iAy, [ay, ay] alma mía!

Stábalo contenplando, como muncho lo quería 
no cesava de llorar, rebentar quasi quería.

20 iAy, [ay, ay] alma mía!

Llantos aze sobre Anttonio que era lástima e mansilla, con la bos muy triste e ronca que desta suerte dezía:

25 ¡Ay, [ay, ay] alma mía!

«Marcanttonio, señor mío, ¿quién yzo tal billanía que dándote a ti la muerte dexando mi alma con vida?

30 ¡Ay, [ay, ay] alma mía!

Cyelo ingiusto y triste zaldo ${ }^{99}$, Deo patria os azía, que lo que gosa en trenta años me avéis quitado en un día

35 ¡Ay, [ay, ay] alma mía!

Pártese para la aposento, sola va y sin conpañía, a naide no dexa entrar porque estar sola quería

40 ¡Ay, [ay, ay] alma mía!

Quando las damas llegaron a palasyo do avía ${ }^{100}$ la postrer palabra oyeron que desta suerte dezía:

45 iAy, [ay, ay] alma mía!

54. Dichoso el año, mes, hora y momento que yo te vi, hermosa ninfa mía; dichoso fue el lugar y claro el día que mereçí gosar de tal contento.

5 Dychoso amor, dichoso pensamiento que de pensar en ti tuvo osadía; dichosa más dichosa fantasía, que tuvo de tal bien conocimiento.

${ }^{99}$ No tengo seguridad en esta lectura (el sentido exigiría hado), como tampoco en el verso siguiente, que parece empezar con el nombre de Cleopatra otra vez.

${ }^{100}$ Acaso quiere escribir vivía. 
Dichoso fue el mirar, pues que te vido,

10 y dichoso el gustar, pues e gustado de verme por tu causa tan perdido.

Dichoso fue el tocar, pues e tocado tu mano, y más dichoso fue el oído, pues que de tus palabras e gustado.

55. Con cinco ricas perlas esmaltado de alabastro y marfil terso y bruñido, de sangre y leche a rededor bañado qual armiño entre rozas escondido

5 o qual de nácar fino relebado y de açendrada placta guarnecido, entre la niebe y el cristal preçioso, un pie dibino vi blanco y ermoso.

56.

Aunque d'esperanças bivo, mi dama no considera que el que 'spera desispera ${ }^{101}$.

Sustentarse d'esperanças no niego que es lo mejor, remedio que al amador con sus favores alcança; pero suele la tardança a veces ser de manera que el que 'spera [desispera].

Mirá, señora, que muero y lo que os pido meresco

10 por lo muncho que padesco y la afición con que os quiero. Mirá, señora, que muero, dad orden como no muera, que el que 'spera desespera.

57. ${ }^{102}$

\section{Canta Rafaelilla,} canta una letrilla;

${ }^{101}$ Refrán que se convierte también en verso por lo menos desde la Égloga de Plácida y Victoriano, de Encina (Teatro completo. Ed. Miguel Ángel Pérez Priego. Madrid: Cátedra, 1991, p. 294).

${ }^{102}$ Composición erótica que recuerda otro poema parecido, la zarabanda que comienza: "Madre que me muero, / llamadme al barbero. / Que me muero madre; /¡barbero y comadre!», que continúa con los versos: "Cuéntese mi pena / y mi mal siniestro / a un barbero diestro» (Poesía erótica del Siglo de Oro, ed. cit., p. 100). 
canta Rafaela, sacarete una muela.

Soy barbero diestro y sacarla juro, no con yerro duro mas con nierbo tiesto ${ }^{103}$

5 porqu' e sido di esto barbero e[n] Sevilla. Canta Rafaelilla.

Quando el gatillo eche $\mathrm{y}$ le venga al giusto

10 será el dolor gusto y la sangre leche; si queréis que arreche soplá la candela. Canta Rafaela.

15 Harto más valdría tener tienda abierta, porque es renta cierta la de cada el día. Dexá la idalgía,

20 que es pelona y pella. Canta Rafaela.

58. ${ }^{104}$

Los pámpanos y sarmientos

el estilo van trocando, y entre los verdes razimos 5 Ucho ho. maduran algunos granos.

${ }^{103} \mathrm{La}$ forma niervo por nervio es normal en este códice.

${ }^{104}$ Uno de los más conocidos romances de Liñán de Riaza. Se recoge en múltiples fuentes, aparte del Romancero general, en el Cancionero de Penagos, en el Romancero de Palacio, etc. La versión presente añade la particularidad del estribillo típico de lo que Frenk denomina «rimas para juegos», en este caso de contenido taurino: "Ucho hó, torillo osquillo" (núm. 2178C). Para que se tenga idea de la deturpación del texto, copio el romance editado por Randolph: «Los pámpanos en sarmientos / el estío va trocando, / y entre los verdes racimos / maduran algunos granos. / Segadas ya las espigas, / son rastrojos los sembrados, / y el labrador con sus eras / tiende parva, y trilla ufano. [...] / En esta sazón Riselo / estaba junto á un ribazo / hecho por las avenidas / de un pedregoso barranco. [...] / Por el cual vio que venía / ya paciendo, ya tascando, / una vaca y un novillo / pisando el agua despacio. / La vaca es baya y cerril, / remendado cuello y manos; / el novillo es hosco y nuevo, / lomo negro y pecho blanco" (Pedro Liñán de Riaza, Poesías. Ed. J. Randolph. Barcelona: Puvill, 1982, p. 191). 
Segadas son las espigas, son anbroxos los sembrados, y el segador en sus eras tiene parva y trío ufano. Ucho ho.

Y en esta sazón Reçelo istaba giunto a un ribacho, echo por las haverías de un pedregoso barrancho. Ucho ho

En esto vio que venía, ya pasiendo, ya tascando, una bacha y un hobillo pisando el agua despacio. Ucho ho.

La vacha es va[ya] y serril, remendada qüello y braço; y el novillo es oscho y nuevo, lomo negro y pecho blanco. Ucho ho.

59.

Vienes de Calis ${ }^{105}$, ¿quereilos guardar los mis amores que andan por la mar?

60. -Linda morenica ${ }^{106}$ en apretura. -Mirá, cavallero, mi desventura.

61. Por encima de los sipreses ${ }^{107}$ mirava la niña los canpos verdes.

62.

Strella que relumbráis ${ }^{108}$, lusero claro del día,

\footnotetext{
105 Acaso haya que entender que el verso está deturpado y que en realidad debería decir "Vientos de Cádiz».

${ }^{106}$ FRENK, núm. 704: «Ojos morenicos / en apretura. ¿Para qué quiere el cavallero / mi desventura?», del cual sería nuestro poema una variante.

107 FRENK, núm. 305 bis, que cita esta fuente. Lo relaciona con el núm. 50: "Por ençima de la oliva /mírame el Amor, mira» (Cancionero de Pedro de Rojas).

${ }^{108}$ Recuerda la cancioncilla tradicional: «Luna que reluces, / toda la noche alumbres» (Frenk, núm. 1072A), que conoce una variante que comienza: «Estrella que reluces». El núm. 1072C presenta una petición del amante a la luna para que alumbre toda la noche a la amada.
} 
que se duerme l' alma mía ¿por qué no la recordáis?

63. ${ }^{109}$

Mirava la mar la mal casada, mirava la mar si es ancha ho larga.

64. Los ojos de la morena ${ }^{110}$ que al alma matan de amor con su donaire e primor asen sabrosa la pena.

65. ${ }^{111}$ Dos contrarios me acen gerra, mayor es que fuego e yelo: el pensamiento en el cielo y la fortuna en la tierra.

66. ${ }^{112} \quad$ Despedida te daré que te llegue a las entrañas, que si de otros te enamores mueras tú a malas lançadas.

67.

Esta doy por despedida ${ }^{113}$ y no quiero cantar más

68.

Quédate a buenas noches ${ }^{114}$, galana, que ya nos vamos qu'estos señores e yo te beceamos las manos.

69.

Aquí venimos, señora ${ }^{115}$, a daros placer a vos;

${ }^{109}$ FRENK, núm. 241. Se recoge en el Cancionero de Pedro de Rojas y en otros muchos. Ha conocido numerosas glosas.

110 Se recoge también en el ms. 22.028 de la BNM con una glosa en varias estrofas. Véase Poesías de fray Melchor de la Serna y otros poetas del siglo XVI, cit., pp. 343-344. Igualmente aparece en el fondo Ottoviano. Cfr. FrenK, núm. 2420.

${ }^{111}$ En el Tesoro de varias poesías de PEDRo PADILla (Madrid: Francisco Sánchez, 1580) se recoge una composición que empieza con el epígrafe: "Redondillas en que se compara la pena de un amante a las que los poetas fingieron que padecen algunos en el infierno» y dice así: "Dos contrarios me dan guerra / con rigurosa estrañeza: / una celestial belleza / y un infierno de la tierra» (f. 204)

112 FRENK, 379bis, que cita esta fuente.

${ }^{113}$ FRENK, núm. 2228bis, que cita esta fuente.

114 FRENK, núm. 1235 ter, que cita esta fuente.

115 FRENK, núm. 1235 bis, que cita esta fuente. 
a quien mal le pareciere mala pasqua le dé Dios.

70.

Quedaos a buenas noches ${ }^{116}$, calanes y moradores, a Dios encomiendo l'alma y a vosotros mis amores.

71. ${ }^{117}$ -Ija mía, ¿qué as tenido? Las colores se te van. - M' a picado, madre mía, en el coño un alacrán.

72.

Asómate a essa ventana ${ }^{118}$, cara de blanco papel, que se van mis compañeros yo quedo para hoder.

73.

Asómate a la ventana ${ }^{119}$ con una olla al pisqüesso verás los tus amores en la calle royendo un güesso.

74.

\section{Dezía la mosa al cura:}

"Pasito, que soy donzella»

y él azía el sordo y dava en ella ${ }^{120}$.

Estando en conversación

quando el cura tratava

a la mosa disculpava

${ }^{116}$ FRENK, núm. 1235 quattor, que cita esta fuente.

117 Parece una variación erótica de un cantarcillo popular, que ya recoge TimonedA en su Sarao de amor: "Morenica qué has tenido / que'l color tienes perdido» (Ed. Carlos Clavería. Barcelona: Delstre's, 1993, p. 9).

118 FRENK, núm. 1949bis: "Asómate a essa ventana,/ cara de borrica flaca...». También en las Poesías del Maestro León: "Asómate a essa ventana,/ perla de oro en caja metida...». Se trata de una canción de ronda claramente continuada aquí en clave erótica.

119 Véase la nota a propósito del poema anterior.

${ }^{120}$ Es un cantarcillo tradicional que se recoge múltiples veces en cancioneros para cantar (no menos de cinco registra САCHO, op. cit., en alguno de los cuales se le denomina "pasacalle», pero no tiene igual glosa que el texto que editamos). Cfr. "Decía la moza al cura: / —iBonito, que soy doncella! / Y él era sordo y daba en ella». (Frenk, núm. 1859bis. Se recoge en el ms. 3924 de la BNM. (Ver Cancionero tradicional. Ed. José María Alín. Madrid: Castalia, 1991, p. 328). Aparece en el Cancionero de Pedro de Rojas, y en varios cancioneros de la propia biblioteca Riccardiana (véase $\mathrm{M}^{\mathrm{a}} \mathrm{T}$. CACHO, Catálogo, cit.). También Correas lo registra como proverbial: «'Pasito, señor, que soy doncella'. Y él era sordo y daba en ella» (Vocabulario de refranes). 
5 y diciendo en conclusión que la culpa no era d'ella. $Y$ él era sordo $y$ dava en ella.

A tal estremo a llegado

10 el padre cura que qüento que salió con su intento mejor que lo que lo inventaron ${ }^{121}$

15 [y él era el sordo $y$ dava en ] ella.

$75 . \quad$ Vos que soys enxabonadera, enxauoname la delantera.

76. Aunque disimules, Juana, bien sabes que a morir boy, pues que m'e de partir hoy y me as de olbidar mañana.

5 Oy, Juana, me partiré, mañana me olbidarás, y con tu olbido berás los quilates de mi fe.

Tu condición ynumana

10 dirá muy bien quién yo soy, pues que me dexas ir hoy por holbidarme mañana.

Bien puedes darme licençia que parta por morir,

15 pues tu olbido a de bivir a la sombra de mi ausençia.

Mas plega a Dios salga bana la queja que de ti doy, y que si me quieres oy

20 que no me olbides mañana.

Con tu olbido no e hallado daño que se me acreçiente, porque e de morir de ausente primero que de olbidado.

${ }^{121}$ A partir de aquí está rota la hoja del manuscrito y no se pude leer lo que falta. 
$25 \quad \mathrm{Y}$ aunque tú seas más humana yo tan desdichado soy que me podrá matar oy el ausencia de mañana.

En la fe de anbos bería un árbol la imagin suya, en lo que es hojas la tuya y en las raíçes la mía.

Muébese la hoja libiana, yo arraigado y firme estoy; tú me dexas partir oy por olbidarme mañana.

Olbidarte es inposible, que en el alma, adonde estás tan bien te conserbarás

40 ingrata como apaçibile.

Díçe[n]me que eres tirana por donde quiera que boy; mas aunque me olbides oy te pienso querer mañana.

Fin.

77. ROMANÇE

De todas las de Genil la más querida pastora, de todas la más ingrata y la más bella de todas,

5 la que enamor[a] las almas $\mathrm{y}$ aun los montes enamora, gloria del famoso Dauro, del Genil honor y gloria.

Por su hermosa ribera

10 sale más que el sol hermosa, de hojas biste las plantas y de rico olor las hojas.

La aurora salió con ella, mas no tan clara el aurora, una rosas esparciendo y hotra imitando a las rosas. 
De flores corona el campo y él dellas le ace corona, Flora le ofrece primicias y ella se las buelbe a Flora.

De aljófar esmalta el prado y de perlas y de aljófar cabello adorna y garganta, que de luz al cielo adorna.

25 Una toca delicada la frente dibina toca senbrando preciosas piedras sobre púrpura preciosa.

A sonbra de unos laureles el mismo amor le açe sonbra y arroxándose a sus pies el arco y flechas arroja.

Sola ba la pastorsilla y como en bellesa es sola la diosa de los amores la reconoçe por diosa.

Por mi choça a despedirse pasó dejando su chosa, llora el alma su partida, que no quiere quien no llora.

Y aunque desdeñosa y fiera no entonçes tan desdeñosa que no conosca el amor, que no ay quien no le conosca.

45 Piadosa buelbe los ojos, ¡ay Dios que la bi piadosa! Obras son tuyas, Amor, y galardón de mis hobras.

$\mathrm{Ba}$ a Loja por su ganado, que 'stá su ganado en Loja bien a costa de un perdido que la bio tan a su costa.

Otra bes lloré su ausencia, que no lo e hecho por hotra, 55 y agora su ausencia lloro pues morir no puedo agora. 
Lisonjas llama mis beras porque ella es toda lisonjas, de quien la adora se burla y soy, triste, quien la adora.

Es tan corta mi esperança y mi bentura tan corta que me sobra que llorar, aunque la bida me sobra.

65 Estórbame el cielo bella y ella también me lo estorba, que se enoja si la beo y muero quando se enoja.

¡Ay, oras, un tiempo alegres, 70 ya por mi mal tristes oras! Memorias de bienes muertos y bibos en mi memoria.

¡Ay, señora de mi bida, $\mathrm{y}$ aun de mil almas señora!

75 Responda ya tu piedad quando amor no corresponda,

que aquestas rocas eladas con no sentir estas rocas a mis congojas se ablandan

80 y tú nunca a mis congojas.

$\mathrm{Y}$ en las ondas deste río y en sus arenas más hondas ${ }^{122}$ mis pocas lágrimas creçen con desçir tú que son pocas.

85 Si a pechos tomas mis daños y de mi bengança tomas, no es tan dichosa mi bida como es mi muerte dichosa

Mas si se te antoja berme,

90 que esto jamás se te antoja, de aquesta mi historia amarga hará amor su dulce historia.

Finis.

${ }^{122}$ Tacha «en las». 
78. OtaVAS [Las luces se me quiebren de mis ojos].

Vaia o venga Fortuna por do quiera, que el corto ho largo tiempo que viviere agora se me $\mathrm{m}[\mathrm{u}]$ estre mansa ho fiera, súbame o baxe donde más quisiere

5 tuyo será, Dardania, asta que muera y más si más, señora, ser pudiere y si gosare el alma hotros despoxos las luçes se me quiebren de mis ojos.

Póngame amor 'n el supremo asento para giustos amantes reservados o llébeme al abismo del tormento a eterno llanto y pena condenado, que gamás alterar mi pensamiento, Dardania, no podrá ageno qüidado

15 y quando me rendiere a otros antojos las luçes se me quiebren de mis ojos.

Sigua su guego el tiempo arrevatado y ejegute en mí solo sus mudanças la tierra, el fuego, el mar, el biento airado crescan o mengüen en mis [---as]; todo lo que ay allá y acá criado causas me hofrescan de desconfianças que se amor me entregare otros a enojos las luçes se me [quiebren de mis ojos].

25 Buelba y rebuelva el çielo presuroso en contra de mi suerte aselerado, Dardania, si tu bello rostro ermoso por hotra ninfa vieres olvidado; la berde ierba deste balle unbroso

30 yamás la pasca marte mi ganado y en ves de flores desechos anbrojos quiébrese las luçes de mis ojos. Fin.

79. [Que al solo soledad le es compañía] ${ }^{123}$.

Dexadme solo, pensamientos tristes ${ }^{124}$; ojos, llorad el mal que me causastes;

${ }^{123}$ No sé de dónde se copia este verso, pero en su formulación recuerda textos como el Grimalte y Gradisa, de JUAN DE FLORES: «Mirad quánto afanado de largo tiempo me veo, que soledad por lo solo rescibo por compañía» (Ed. Carmen Parrilla. Santiago de Compostela: Universidad de Santiago, 1988 p. 30).

${ }^{124}$ Este primer verso recuerda a de un soneto de Lope: «Dexadme un rato, 
coraçón que tan alto me subistes, batid las alas de donde os alsastes; memoria que otro tiempo alegre fuistes, huid, que con mi bien os acavastes. Quédese sola la tristesa mía, que al solo soledad l'es compañía.

Quedaos a Dios, hermoso vaglle y prado [de] frescas sombras ${ }^{125}$ y de flores lleno, campo florido donde mi ganado pacía la yerba por el verde seno, claras puras corrientes do el dorado rayo de mi sol vistes más sereno

15 sin él, sin vos me voy triste e sin guía, que al solo soledad l' es compañía.

Espesso monte, selva de frescura, dichosa bega, arroyo christalino, árboles que eçedéis 'n el altura al ciprés, al abet, al aya, al pino; tanto el cielo os conçeda de ventura quanto a mí de desdicha mi destino, pues yo no veré más vuestra alegría que al solo soledad l' es compañía.

25 O Dardania cruel, ermosa y dura, o tirana esención, o bella fiera, o divina beldad donde natura çifró quanto del çielo acá se espera; ya yo me parto y sin tu ermosura

30 ni espero bien ni nunca el çielo quiera que aqueste venga para mí algún día que al solo soledad l' es compañía.

Honda, zurrón, gabán, rabel, caiado que un tiempo prendas de Dardania fuistes; flauta que entre el coral, marfil preçiado de ella el divino aliento despedistes, cabaña, dulce alberge y vos, ganado, que a vezes a su amparo os acogistes, quedaos d'os bea la enmiga mýa que al solo soledad l'es compañía.

Vos, sampoña, que en todo el monte entorno mover açía vuestro dulce asento

pensamientos tristes, / que no me he de rendir a vuestra fuerça» (Rimas, ed. de Felipe Pedraza. Madrid: Universidad de Castilla-La Mancha, 1993, I, p. 309).

${ }^{125}$ En el original $y$ fresca sombras. 
sin que fiera de todo este contorno no suspendiese y hasta el manso biento

45 laurel, acanto, lirio, rossa, adorno de su preçiosa frente sacro asiento, dezid dónde el injusto amor me enbía que al solo soledad l' es compañía.

50 la tuia tantas veçes escondistes, vella Diana, que por la fragosa sierra de mi Dardania huiendo fuiste; e[s]trellas, cielo, alba luminosa que con mi ninfa al mundo amanecistes;

55 no me sigáis, dexadme en mi porfía, que al solo soledad l' es compañía.

Tan solo a vos os pido, claro río, que si la causadora de mi daño la ardiente siesta y caluroso estío

60 quisiere en vos parar que llanto [?]año que os buelve en fuego sin dezir que 's mío le diréis y estas quejas que me engaño huí de piedad de la desdicha mía quiçá que buscará mi compañía. Fin

80. Yo, señora, te [he] dado el alma y vida y, si tubiera más que dar, más diera; quisiera más querer si más pudiera siendo aun mi voluntad aborrecida.

5 A un alma tan sugeta y tan rendida tanta fe, tan firme y verdadera ¿qué recompensa das sino que muera aun no ciendo mi pena agradecida?

Vesme regar de lágrimas la tierra

10 y con suspiros enflamar el cielo y duras en azerme mortal gerra.

Naide me dé speransa ni consuelo, pues tu crueldad me aparta y me destierra fálteme el cielo, el aire, el agua, el suelo.

81. ${ }^{126}$ Vivan eternamente mis cuidados y tu beldad y gloria todo giunto,

${ }^{126} \mathrm{El}$ soneto se recoge también en el cancionero RI/6 de la misma biblioteca un conjunto de poemas dirigido a una monja llamada doña Beatriz. Se encabeza ahí como "Soneto al retrato" y aparece también como anónimo. 
no se cansen ni dexen solo un punto

de estar mi cuerpo e alma así abrasados.

5 No lla[men] duros ya mis duros hados, pues he podido ver aquel trasunto divino donde están punto por punto los ángeles del cielo retractados.

Ya mi cansada fuerça es reparada,

10 qual la fenis en fuego he revivido, el alma queda en ti glorificada.

No tengas tanto bien tan escondido, pues que basta a quitar la fuerça airada a la muerte y al tiempo y al olvido.

82. SONETO

Sy tanto gusto tengo en el tormento, si allo 'n el penar tanta alegría que por gloria ninguna trocaría la que goso en mi mal y discontento,

5 ¿qué fuera a tener vos el sentimiento que padeçe por vos el alma mía y que en entrambas partes a porfía creçiera amor con dulçe acogimiento?

¡O quál fuera la gloria del goçaros!
Mas como naide puede mereceros naide deve tampoco desearos,

si no es que vos queráis enterneceros y con la ley de amor sola y guardaros con quien pudo sin término quereros. 
ÍNDICE DE NOMBRES DE PERSONA (EN CURSIVA, LOS NOMBRES POÉTICOS; EN NEGRITA, AQUELLOS QUE INDICAN AUTORÍA DE LOS POEMAS)

Anónimo, 5, 6, 7, 8, 9, 10, 11, 12, 13, 14, 15, 16, 17, 18, 19, 20, 21, 22, 23,

$24,25,26,27,28,29,32,35,42,43,44,45,46,47,48,49,50,51,52$,

$54,55,56,57,59,60,61,62,63,64,65,66,67,68,69,70,71,72,73$,

$74,75,76,77,78,79,80,81,82$.

Clarinda. Vid Zamudio, Catalina.

Dardania, 78, 79 .

Daroca, Vicenta, 53.

Juana, 76.

Liñán de Riaza, Pedro, 58.

Montesa, Maestre de, 31

Recelo. Vid. Liñán de Riaza, Pedro.

Solisa, 33, 34.

Sotomayor, Licenciado, 33, 34.

Villegas, doctor, 1.

Vireno. Vid. Vivar, Juan Bautista..

Vivar, Juan Bautista, 1, 2, 4, 30, 31, 36, 37, 38, 39, 40, 41, 46.

Zamudio, Catalina, 3, 4.

ÍNDICE DE PRIMEROS VERSOS; LOS ESTRIBILLOS O VERSOS QUE SE GLOSAN, EN CURSIVA. (SE HA ACTUALIZADO LA GRAFÍA PARA AYUDAR

\section{A LA LOCALIZACIÓN)}

A una ventana me puse, 39.

Al amor porque es poner, 16.

$\mathrm{Al}$ encendido amador, 16.

Amar la noche, aborrecer el día, 44.

Amor de malicia lleno, 9.

Aquí venimos, señora , 69 .

Asómate a esa ventana, 72.

Asómate a la ventana, 73 .

Aunque de esperanzas vivo, 56.

Aunque disimules, Juana, 76.

Bésame, niña mía, que tus besos, 43.

Bien es que el perro provoque, 5 .

Bien puede en cualquier estado, 38 .

Buscome la muerte en vos, 11.

Cansado ya de sufrir, 12.

Canta, Rafaelilla, 57.

Con cinco ricas perlas esmaltado, 55 .

Con tu fiesta, Virgin pura, 18.

Cortó la parca el hilo y despojado, 36.

Crecieron y crecerán, 45.

Cuando pienso vivir, muero, 7 .

Cuanto más tarde más verde, 10. 
De quién, sino de mí, puedo quejarme, 27.

De todas las de Genil, 77.

Decía la moza al cura, 74.

Dejadme solo, pensamientos tristes, 79.

Despedida te daré, 66.

Dichoso el año, mes, hora y momento, 54.

Dios herido el costado con la llaga, 36.

Dos contrarios me hacen guerra, 65 .

Dos hombres vi razonar, 19.

El firme amador que alcanza, 10.

En agua convertido, 42.

En la cruz que sí que no, 24.

En medio de las altas aguas unas, 21.

En una hermosa unión, 29.

En una tabla esculpida, 40.

Engáñaste, Clarinda, que el engaño, 4.

Es imposible asegurar la vida, 22.

Esta doy por despedida, 67.

Estando en conversación, 74.

Este bien en que me veo, 28.

Este perro tiene cúyo, 5.

Esto doy por despedida, 64?.

Estrella que relumbráis, 62 .

Excelso monte, cuya altiva frente, 31 .

Firme estaré en mi dolor, 6.

Fortuna, tinta y ventana, 39.

Ha sido siempre el bélico ejercicio, 26.

Habiendo crucificado, 24.

Hiciera la tabla arder, 40.

Hija mía, ¿qué has tenido?, 71.

Insigne reina Cleopatra, 53.

La crueza y hermosura, 49.

La más hermosa que Dios, 29.

La vida el que pudiere la asigure, 22.

Lágrimas que no pudieron, 41.

Las luces se me quiebran de los ojos, 78.

Limosna que ansí enriquece, 30.

Linda morenica, 60.

Lloren los enamorados, 41.

Lo largo es falso, es corcho lo más bello, 35 .

Los ojos de la morena, 64.

Los ojos vueltos, que del negro dellos, 23.

Los pámpanos y sarmientos, 58.

Marta, aunque de vos se canta, 20.

Mil impresas veo traer, 14.

Mil veces deseo morir, 7 .

Miraba la mar, 63.

Ninguno desespere, 47.

No debe de ser por bien, 8.

No fíes de tu alegría, 46. 
No más, Solisa, no, baste lo hecho, 34 .

No puede dejar de eser, 6.

Noche serena, alegre, clara y pura, 44.

Obra duro jamás fue en ella oído, 37.

Oh fealdad, sepultura, 48.

Ojos me queréis hacer, 15.

Plega a Dios que si se ensaya, 17.

Por encima de los cipreses, 61.

Porque es con tu fiesta el suelo,18.

Porque estaba en vuestra cumbre, 11.

Porque luego ciego Amor, 45.

Porque tu cabello cuyo, 14.

Pues estáis en las aguas zabullidas, 21.

Que al solo soledad le es compañía, 79.

Que me da contento, 52.

Que si en santa os igualó, 20.

Que si la vida me enoja, 12.

Quedaos a buenas noches, 70 .

Quédate a buenas noches, 68 .

Quien se descuida no ama, 8.

Se tiene en menos que cuando, 19.

$\mathrm{Si}$ al sol is a buscar, busca a Solisa, 33 .

Si el tiempo y la ocasión me ha demostrado, 27.

Si la ponzoña fiera del engaño, 3 .

Si puede amor con flechas de tus ojos, 23.

Si tanto gusto tengo en el tormento, 82 .

Sin mujeres el mundo y el bien dellas, 50 .

Sin ser hijo de San Pedro, 13.

Sola vos podéis hacerme, 15 .

Soy barbero diestro, 57.

Su gran torre Nembrot edificaba, 37 .

Su gusto es verme sin él, 9.

Sustentarse de esperanzas, 56.

Tomada está la posada, 28.

Tristeza, si a un alma triste, 32.

Tú o más, Solisa, no baste lo hecho, 34 .

Un alma a do la tristeza, 32.

Un anillo muy preciado, 51 .

Un día que yo trataba, 17 .

Una hermosa dama, 52.

Vaya o venga Fortuna por do quiera, 78.

Vienes de Calis, 59.

Vireno, aquella blanca, hermosa yedra, 1 .

Vivan eternamente mis cuidados, 81 .

Vos, que sois enjabonadera, 75.

Vuestros alfileres son, 25.

$Y \sin$ bonete pues no, 13, 38.

Ya yo me acuerdo ver tu amada yedra, 2 .

Yo, señora, te he dado el alma y vida, 80 